\title{
The Effect of Financial Development on Convergence: Theory and Evidence
}

\section{Citation}

Aghion, Philippe, Peter Howitt, and David Mayer-Foulkes. 2005. The effect of financial development on convergence: Theory and evidence. Quarterly Journal of Economics 120, no. 1: 173-222.

\section{Published Version}

http://dx.doi.org/10.1162/qjec.2005.120.1.173

\section{Permanent link}

http://nrs.harvard.edu/urn-3:HUL.InstRepos:4481509

\section{Terms of Use}

This article was downloaded from Harvard University's DASH repository, and is made available under the terms and conditions applicable to Other Posted Material, as set forth at http:// nrs.harvard.edu/urn-3:HUL.InstRepos:dash.current.terms-of-use\#LAA

\section{Share Your Story}

The Harvard community has made this article openly available.

Please share how this access benefits you. Submit a story.

\section{Accessibility}




\title{
THE EFFECT OF FINANCIAL DEVELOPMENT ON CONVERGENCE: THEORY AND EVIDENCE**
}

\author{
Philippe Aghion \\ Peter HowitT \\ David MaYer-FoulKes
}

\begin{abstract}
We introduce imperfect creditor protection in a multicountry Schumpeterian growth model. The theory predicts that any country with more than some critical level of financial development will converge to the growth rate of the world technology frontier, and that all other countries will have a strictly lower long-run growth rate. We present evidence supporting these and other implications, in the form of a cross-country growth regression with a significant and sizable negative coefficient on initial per-capita GDP (relative to the United States) interacted with financial intermediation. In addition, we find that other variables representing schooling, geography, health, policy, politics, and institutions do not affect the significance of the interaction between financial intermediation and initial per capita GDP, and do not show any independent effect on convergence in the regressions. Our findings are robust to removal of outliers and to alternative conditioning sets, estimation procedures, and measures of financial development.
\end{abstract}

\section{INTRODUCTION}

Most current theories of the cross-country distribution of per-capita income imply that all countries share the same longrun growth rate (of TFP or per-capita GDP). Yet the historical record shows that growth rates can differ substantially across countries for long periods of time. For example, Pritchett [1997] estimates that the proportional gap in per-capita GDP between the richest and poorest countries grew more than fivefold from 1870 to 1990, and according to the tables in Maddison [2001] the proportional gap between the richest group of countries and the poorest ${ }^{1}$ grew from 3 in 1820 to 19 in 1998.

The "great divergence" between rich and poor countries continued through the end of the twentieth century. Although many

* With the usual caveat we thank Daron Acemoglu, Alberto Alesina, Jess Benhabib, Sean Campbell, Sebnem Kalemli-Ozcan, Ross Levine, Andrei Shleifer, David Weil, three anonymous referees, and participants at the 2003 NBER Summer Institute, McMaster University, the 2003 Canadian Macroeconomics Study Group, the Federal Reserve Board, Brigham Young University, New York University, and Harvard University for helpful comments. Cristina Santos and Stylianos Michalopoulos provided excellent research assistance.

1. The richest group was Western Europe in 1820 and the "European Offshoots" (Australia, Canada, New Zealand, and the United States) in 1998. The poorest group was Africa in both years.

$\odot 2005$ by the President and Fellows of Harvard College and the Massachusetts Institute of Technology.

The Quarterly Journal of Economics, February 2005 
studies ${ }^{2}$ show that a large group of rich and middle-income countries have been converging to parallel growth paths over the past 50 years or so, the gap between these countries as a whole and the very poorest countries as a whole has continued to widen. For example, the proportional gap in per-capita GDP between MayerFoulkes's [2002] richest and poorest convergence groups grew by a factor of 2.6 between 1960 and 1995, and the proportional gap between Maddison's richest and poorest groups grew by a factor of 1.75 between 1950 and 1998 .

Technology appears to be the central factor underlying divergence. Easterly and Levine [2001] estimate that about 60 percent of the cross-country variation in growth rates of per-capita GDP is attributable to differences in productivity growth, while Klenow and Rodríguez-Clare [1997] estimate that in their sample about 90 percent of the variation is attributable to differences in productivity growth. Although the level of productivity can be affected by many factors other than technology, such as geography and institutions that affect the efficiency of resource allocation, it is hard to see how substantial differences in the growth rate of productivity persisting for such long periods of time can be accounted for by these nontechnological factors, which are themselves highly persistent over time. Instead, it seems more likely that divergence reflects long-lasting cross-country differences in rates of technological progress.

These facts are especially puzzling when one takes into account the possibility of international technology transfer and the "advantage of backwardness" [Gerschenkron 1952] that it confers on technological laggards. That is, the further a country falls behind the world's technology leaders, the easier it is for that country to progress technologically simply by implementing new technologies that have been discovered elsewhere. Eventually this advantage should be enough to stabilize the proportional gap that separates it from the leaders. This is what happens in neoclassical models where technology transfer is instantaneous [Mankiw, Romer, and Weil 1992], where technologies developed on the frontier are not "appropriate" for poorer countries [Basu and Weil 1998; Acemoglu and Zilibotti 2001], where technology transfer can be blocked by special

2. For example, Barro and Sala-i-Martin [1992], Mankiw, Romer, and Weil [1992], and Evans [1996]. 
interests [Parente and Prescott 1994, 1999] and where a country adopts institutions that impede technology transfer [Acemoglu, Aghion, and Zilibotti 2002].

This paper explores the hypothesis that financial constraints prevent poor countries from taking full advantage of technology transfer and that this is what causes some of them to diverge from the growth rate of the world frontier. It introduces credit constraints into a multicountry version of Schumpeterian growth theory with technology transfer, ${ }^{3}$ and shows that the model implies a form of club convergence consistent with the broad facts outlined above. In the theory, countries above some threshold level of financial development will all converge to the same longrun growth rate, and all other countries will have strictly lower long-run growth rates.

There are three key components to the theory. The first is that because technological knowledge is often tacit and circumstantially specific, ${ }^{4}$ technology transfer requires the receiving country to invest resources in order to master foreign technologies and adapt them to the local environment. Although these investments may not fit the conventional definition of $R \& D$, they play the same role as R\&D in an innovation-based growth model; that is, they generate new technological possibilities where they are conducted, building on previous knowledge. ${ }^{5}$ Accordingly, our theory assigns to R\&D the role that Nelson and Phelps [1966] assumed was played by human capital, namely that of determining a country's "absorptive capacity." 6

The second key component is the assumption that as the global technology frontier advances, the size of investment required in order to keep innovating at the same pace as before

3. See Aghion and Howitt [1998], Howitt [2000], Acemoglu, Aghion, and Zilibotti [2002], and Howitt and Mayer-Foulkes [2002]. The last of these papers implies three convergence groups, analogous to the three groups of the present paper, but the disadvantage of backwardness that prevents some countries from converging in that paper arises from low levels of human capital rather than from credit-market imperfections.

4. See Arrow [1969] and Evenson and Westphal [1995].

5. Cohen and Levinthal [1989] and Griffith, Redding, and Van Reenen [2001] have also argued that $R \& D$ by the receiving country is a necessary input to technology transfer.

6. Grossman and Helpman [1991] and Barro and Sala-i-Martin [1997] also model technology transfer as taking place through a costly investment process, which they portray as imitation; but in these models technology transfer always leads to convergence in growth rates except in special cases studied by Grossman and Helpman where technology transfer is inactive in the long run. 
rises in proportion. This assumption recognizes the force of increasing complexity, which makes technologies increasingly difficult to master and to adapt to local circumstances. ${ }^{7}$

The third key component is an agency problem that limits an innovator's access to external finance. Specifically, we assume that an innovator can defraud her creditors by hiding the results of a successful innovation, at a cost that depends positively on the level of financial development. Because of this, in equilibrium the innovator's access to external finance will be limited to some multiple of her own wage income. Since wages are limited by domestic productivity, therefore a technological laggard can face a disadvantage of backwardness that counteracts Gerschenkron's advantage; that is, the further behind the frontier it falls the less its innovators will be able to invest relative to what is required in order to keep innovating at a given rate. The lower the level of financial development in the country the greater will be this disadvantage.

Our paper relates to several important strands of theory relating growth, convergence, and financial-market development. There is first the literature on poverty traps and interpersonal convergence or divergence in economies with credit market imperfections, in particular Banerjee and Newman [1993], Galor and Zeira [1993], Aghion and Bolton [1997], and Piketty [1997]. In these models,${ }^{8}$ all agents face the same production technology and, unlike in our model, the same (productivity-adjusted) investment costs, ${ }^{9}$ and what generates poverty traps are either nonconvexities in production or monitoring, or pecuniary externalities working through factor prices. However, there is no technical progress and therefore no positive long-run growth in these models, which therefore cannot analyze the issue of long-term convergence in growth rates.

Another literature analyzes the effects of financial constraints or financial intermediation on long-term growth. Thus,

7. A similar assumption has been shown elsewhere to be helpful in accounting for the fact that productivity growth rates have remained stable in OECD countries over the second half of the twentieth century despite a steady increase in R\&D expenditures. See Jones [1995] and Howitt [1999].

8. See Banerjee [2003] for a comprehensive survey of this literature.

9. In contrast, in our model countries face a productivity-adjusted cost of innovation which increases with its distance to the technological frontier. It is the interplay between credit constraints and this technological heterogeneity which generates the possibility of long-term divergence. 
Greenwood and Jovanovic [1990], Levine [1991], Bencivenga and Smith [1991, 1993], Saint-Paul [1992], Sussman [1993], Harrison, Sussman, and Zeira [1999], and Kahn [2001] analyze the effects of financial intermediation on growth in an AK-style model with no distinction being made between investing in technology and investing in physical or human capital. King and Levine [1993b], de la Fuente and Marin [1996], Galetovic [1996], Blackburn and Hung [1998], and Morales [2003] consider the relationship between finance and growth in the context of innovationbased growth models. De Gregorio [1996] studies the effects on growth of financial constraints that inhibit human capital accumulation. Krebs [2003] shows how imperfect sharing of individual human-capital risk can depress long-run growth. However, none of these models analyzes the process of technology transfer that we are focusing on, and therefore none of them is capable of addressing the question of why technology transfer is not sufficient to put all countries on parallel long-run growth paths.

The paper also produces evidence to support its main implications. There is already a substantial body of evidence ${ }^{10}$ to the effect that financial development is an important determinant of a country's short-run growth rate, almost all of which is predicated on the assumption of long-run convergence in growth rates. We extend this analysis to allow for the possibility of different long-run growth rates, using a cross section of 71 countries over the period 1960-1995. Specifically, we use the same data, conditioning sets, instruments, and robustness checks as Levine, Loayza, and Beck [2000], who found a strong and robust effect of the level of financial development in a standard cross-country growth regression. We add to their regression an interaction term between the log of initial per-capita GDP (relative to the United States) and financial development, and interpret a negative coefficient as evidence that low financial development makes convergence less likely. We find that the coefficient is indeed negative, and is large both statistically and economically.

Our empirical methodology is similar to that of Benhabib and Spiegel [2005], who found a negative interaction term between initial TFP and schooling and concluded that schooling was a key determinant of whether or not a country will converge to the frontier

10. See the surveys by Levine [1997, 2005] and the book by Demirgüç-Kunt and Levine [2001]. 
growth rate. We test the robustness of our results by including both schooling and an interaction term between the initial GDP gap and schooling as additional regressors in our equation. In addition, we repeat this robustness test using instead of schooling a large number of different variables suggested by other growth theories. In all cases the main implications of our theory pass the test. We also present evidence to the effect that the main channel through which financial development affects convergence is productivity growth, as implied by the theory, rather than capital accumulation, and show that our results are robust to elimination of outliers, to alternative conditioning sets, to alternative estimation procedures and to alternative measures of financial development.

\section{Theoretical Framework}

We follow Acemoglu, Aghion, and Zilibotti [2002] in casting Schumpeterian growth theory in a simple discrete-time framework. There are $m$ countries, who do not exchange goods or factors, but do make use of each others' technological ideas. There is a continuum of individuals in each country. Each country has a fixed population $P$, which for notational convenience we normalize to unity. Thus, aggregate and per-capita quantities are identical. Everyone lives for two periods, being endowed with two units of labor services in the first period and none in the second, with a utility function linear ${ }^{11}$ in consumption: $U=c_{1}+\beta c_{2}$, where $0<\beta<1$. Within each country the growth path is determined as follows.

\section{II.A. The General Sector}

There is one multipurpose "general" good, produced by labor and a continuum of specialized intermediate goods according to the production function,

11. Linear utility implies that people are indifferent between investing in any country, whether technologically or financially developed or not. We assume that all investment is locally financed, but if $\beta$ were the same across all countries, we could allow perfect capital mobility with no change in the analysis. Extending our analysis to the case of strictly concave utility would allow us to analyze the possibility and implications of capital flowing from less to more financially developed economies in accordance with Lucas' [1990] oft-cited observation that capital flows from poor to rich countries rather than the reverse. 


$$
Z_{t}=P^{1-\alpha} \int_{0}^{1} A_{t}(i)^{1-\alpha} x_{t}(i)^{\alpha} d i, \quad 0<\alpha<1,
$$

where $x_{t}(i)$ is the input of the latest version of intermediate good $i$ and $A_{t}(i)$ is the productivity parameter associated with it. The general good is used for consumption, as an input to R\&D and also as an input to the production of intermediate goods.

The general good is produced under perfect competition, so the price of each intermediate good equals its marginal product:

$$
p_{t}(i)=\alpha\left(\frac{x_{t}(i)}{A_{t}(i)}\right)^{\alpha-1}
$$

(We use the general good as numéraire, and $P=1$.)

\section{II.B. Intermediate Sectors}

For each intermediate good $i$ there is one person born each period $t-1$ who is capable of producing an innovation for the next period. This person is called the $i$ th innovator in $t-1$, and if she succeeds (innovates), then she will be the $i$ th incumbent in $t$. Let $\mu_{t}(i)$ be the probability that she succeeds. Then

$$
A_{t}(i)=\left\{\begin{array}{ll}
\bar{A}_{t} & \text { with probability } \mu_{t}(i) \\
A_{t-1}(i) & \text { with probability } 1-\mu_{t}(i)
\end{array}\right\},
$$

where $\bar{A}_{t}$ is the world technology frontier, which grows at the constant rate $g>0$, taken as given for now. The fact that a successful innovator gets to implement $\bar{A}_{t}$ is a manifestation of technology transfer, of the kind that Keller [2002] calls "active"; that is, domestic R\&D makes use of ideas developed elsewhere in the world. ${ }^{12}$

12. In Aghion, Howitt, and Mayer-Foulkes [2004] we extend our analysis and results to the more general case in which innovations do not result in an immediate jump to the frontier, so that

$$
A_{t}(i)=\left\{\begin{array}{ll}
b \bar{A}_{t}+(1-b) A_{t-1} & \text { with probability } \mu_{t}(i) \\
A_{t-1}(i) & \text { with probability } 1-\mu_{t}(i)
\end{array}\right\},
$$

where

$$
A_{t}=\int_{0}^{1} A_{t}(i) d i
$$

is the average domestic productivity at date $t$ and $b$ is a real number between 0 and 1. 
In each intermediate sector where an innovation has just occurred, the incumbent is able to produce any amount of the intermediate good using as the sole input one unit of the general good per unit of intermediate good. In addition, in every intermediate sector there are an unlimited number of people capable of producing copies of the latest generation of that intermediate good at a unit cost of $\chi>1$. $^{13}$

So in sectors where an innovation has just occurred, the incumbent will be the sole producer, at a price equal to the unit cost of the competitive fringe, ${ }^{14}$ whereas in noninnovating sectors where the most recent incumbent is dead, production will take place under perfect competition with a price equal to the unit cost of each producer. In either event the price will be $\chi$, and according to the demand function (2) the quantity demanded will be

$$
x_{t}(i)=\left(\frac{\alpha}{\chi}\right)^{1 /(1-\alpha)} A_{t}(i) .
$$

It follows that an unsuccessful innovator will earn zero profits next period, whereas the profit of an incumbent will be $\pi_{t}(i)=$ $\pi \bar{A}_{t}$, where $\pi=(\chi-1)(\alpha / \chi)^{1 /(1-\alpha)}$.

\section{II.C. Aggregate Behavior}

Define the country's "average productivity" $A_{t}$ as

$$
A_{t}=\int_{0}^{1} A_{t}(i) d i .
$$

Substituting (3) into (1), we see that gross output of the general good will be

$$
Z_{t}=\zeta A_{t},
$$

where $\zeta=(\alpha / \chi)^{\alpha /(1-\alpha)}$.

In equilibrium the probability of innovation will be the same in each sector: $\mu_{t}(i)=\mu_{t}$ for all $i$; therefore, average productivity evolves according to

13. Thus, imitation of a successful innovation is costless within a country, whereas we shall assume below that, because of the well-documented fact that technologies work differently in different countries, moving a domestic sector up to the world technology frontier is costly and requires a positive R\&D investment.

14. This requires the further assumption that $\chi<\alpha^{-\alpha}$, which we now make. 


$$
A_{t}=\mu_{t} \bar{A}_{t}+\left(1-\mu_{t}\right) A_{t-1} .
$$

That is, the productivity parameter will equal $\bar{A}_{t}$ in the fraction $\mu_{t}$ of sectors that innovated at $t-1$, but will remain equal to $A_{t-1}(i)$ in the $1-\mu_{t}$ sectors that did not innovate at $t-1$, and since innovations are distributed randomly across sectors the average value of $A_{t-1}(i)$ among noninnovating sectors will equal the economywide average $A_{t-1}$.

Define the country's normalized productivity as

$$
a_{t}=A_{t} / \bar{A}_{t} .
$$

Normalized productivity is an inverse measure of the country's distance to the technological frontier, or its "technology gap." It follows that the gap evolves according to

$$
a_{t}=\mu_{t}+\frac{1-\mu_{t}}{1+g} a_{t-1} .
$$

Since the general sector is perfectly competitive, the wage rate $w_{t}$ will be the marginal product of labor in producing the general good:

$$
w_{t}=(1-\alpha) Z_{t}=(1-\alpha) \zeta A_{t} .
$$

The fact that $w_{t}$ is proportional to domestic productivity $A_{t}$ plays an important role in what follows. For as we shall see, it implies that technology investment in a country that is credit-constrained will be strictly proportional to $A_{t}$.

Value added in the general sector is wage income, whereas value added in the intermediate sectors is profit income. Percapita GDP is the sum of value added in all sectors:

$$
Y_{t}=w_{t}+\mu_{t} \pi_{t}=(1-\alpha) \zeta A_{t}+\mu_{t} \pi \bar{A}_{t} .
$$

\section{II.D. Innovations}

In each sector the $R \& D$ investment needed to innovate at any given rate $\mu_{t}$ is governed by the cost function,

$$
N_{t-1}=\tilde{n}\left(\mu_{t}\right) \bar{A}_{t}=\left(\eta \mu_{t}+\delta \mu_{t}^{2} / 2\right) \bar{A}_{t} \quad \eta, \delta>0,
$$

where $N_{t-1}$ is the quantity of general good that must be invested. We multiply $\tilde{n}$ by $\bar{A}_{t}$ to recognize the "fishing-out" effect; the further ahead the frontier moves, the more difficult it is to innovate. This effect is crucial in what follows. 
In our analysis below, we make extensive use of the inverse of the R\&D cost function $\tilde{n}$. Namely, an intermediate producer who invests the amount $n \bar{A}_{t}$ in R\&D will innovate next period with probability ${ }^{15}$

$$
\tilde{\mu}(n)=\tilde{n}^{-1}(n)=\left(\sqrt{\eta^{2}+2 \delta n}-\eta\right) / \delta .
$$

Finally, we assume that

$$
\eta<\beta \pi<\eta+\delta .
$$

This condition guarantees that the equilibrium probability $\mu_{t}$ will always lie strictly between 0 and 1 .

In equilibrium $\mu_{t}$ will be chosen so as to maximize the expected net payoff

$$
\beta \mu_{t} \pi \bar{A}_{t}-\tilde{n}\left(\mu_{t}\right) \bar{A}_{t}
$$

in each sector, subject to credit constraints.

\section{II.E. Equilibrium Innovation under Perfect Credit Markets}

In this subsection we show that if innovators had unlimited access to outside finance all economies would converge to the same growth rate. The level of each country's growth path might be different because of country-specific differences in parameters such as $\beta$ and $\chi$, but their long-run growth rates would all be the same.

Suppose accordingly that each innovator can borrow (from other young people) unlimited quantities at the going rate $r=$ $\beta^{-1}-1$ subject to a binding commitment to repay if the project succeeds. Then $\mu_{t}$ will be chosen so as to maximize (6) with no constraint. This implies that $\mu_{t}=\mu^{*}$, where

$$
\mu^{*}=(\beta \pi-\eta) / \delta,
$$

with corresponding equilibrium $R \& D$ expenditure

$$
N_{t-1}^{*}=\tilde{n}\left(\mu^{*}\right) \bar{A}_{t}=n * \bar{A}_{t} .
$$

It follows from this and equation (4) that the country's technology gap evolves according to

$$
a_{t+1}=\mu^{*}+\frac{1-\mu^{*}}{1+g} a_{t} \equiv H_{1}\left(a_{t}\right),
$$

15. Note that $\tilde{\mu}(0)=0, \tilde{\mu}^{\prime}(n)>0$ and $\tilde{\mu}^{\prime \prime}(n)<0$. 
which converges in the long run to the steady-state value $\mathrm{e}^{16}$

$$
a^{*}=\frac{(1+g) \mu^{*}}{g+\mu^{*}} \in(0,1) \text {. }
$$

Per-capita GDP in the steady state is

$$
Y_{t}^{*}=\left[(1-\alpha) \zeta a^{*}+\mu^{*} \pi\right] \bar{A}_{t},
$$

which grows at the same rate $g$ as the technology frontier $\bar{A}_{t}$, as claimed.

\section{II.F. Credit Constraints}

Now suppose that credit markets are imperfect. Each entrepreneur at the end of period $t$ is a young person with access to the wage income $w_{t}$. Thus, to invest $N_{t}$ in an R\&D project, she must borrow $N_{t}-w_{t}$. Assume that if she pays a cost $c N_{t}$ she can defraud her creditors by hiding the proceeds in the event that the project is successful. This implies that in equilibrium the entrepreneur cannot borrow more than a finite multiple of her accumulated wealth ${ }^{17} w_{t}$, as in Bernanke and Gertler [1989], and therefore she cannot invest more than

$$
v w_{t}
$$

in innovation, where $v \in[1, \infty)$ depends positively on the hiding cost $c$.

This credit constraint will be binding if the unconstrained optimal investment $n * \bar{A}_{t+1}$ is strictly greater than the innovator's investment capacity $v w_{t}$, or equivalently, after dividing through by $\bar{A}_{t+1}$, if

$$
n^{*}>a_{t} \omega
$$

where

$$
\omega \equiv \frac{\nu(1-\alpha) \zeta}{1+g}
$$

16. The result that $a^{*}$ is strictly less than one reflects the fact that no country, even the most technologically advanced in terms of its average productivity, will ever be the world leader in all intermediate sectors simultaneously, because of the randomness of the innovation process. Thus, the model is consistent with the evidence of Baily and Solow [2001] to the effect that different countries are technology leaders in different industries.

17. See Appendix 1. 
We represent financial development by the cost parameter $c$, or equivalently by the credit multiplier $v$ (or by $\omega$ ), on the grounds that a highly developed financial system protects creditors by making it hard to defraud them.

We see from (9) that (i) for a given level of technological development $a_{t}$ of the country, domestic firms are more likely to be credit-constrained if financial development $\omega$ is lower; (ii) for a given level of financial development $\omega$ firms are more likely to be credit-constrained the further the country is behind the technological frontier (i.e., the smaller is $a_{t}$ ). This is the "disadvantage of backwardness" induced by the existence of credit constraints. ${ }^{18}$

Thus, firms in more advanced countries with

$$
a_{t}>n * / \omega \equiv \underline{a}(\omega)
$$

will invest the unconstrained amount $n * \bar{A}_{t+1}$ in innovation and therefore will innovate with probability $\mu^{*}$, whereas firms in less advanced countries with

$$
a_{t}<n^{*} / \omega \equiv \underline{a}(\omega)
$$

cannot invest more than $\nu w_{t}=a_{t} \omega \bar{A}_{t+1}$ and therefore will innovate with probability

$$
\tilde{\mu}\left(a_{t} \omega\right)<\mu^{*},
$$

where the innovation technology $\tilde{\mu}$ is given by (5). ${ }^{19}$

In that case $a_{t+1}$ will be determined according to

$$
a_{t+1}=\tilde{\mu}\left(\omega a_{t}\right)+\frac{1-\tilde{\mu}\left(\omega a_{t}\right)}{1+g} a_{t} \equiv H_{2}\left(a_{t}\right) .
$$

18. Our model implies that, holding the credit multiplier $v$ (or $\omega$ ) constant, among those countries that are financially constrained external financing (equal to $\left.(v-1) w_{t}\right)$ is bigger in those that are closer to the technological frontier. However, the opposite is true among those countries that are not constrained, as the amount of external financing is then entirely determined by the gap between the R\&D cost $n * \bar{A}_{t}$, which is proportional to the frontier productivity $\bar{A}_{t}$, and the amount of internal finance which is proportional to current domestic productivity.

19. This raises the question of why a constrained entrepreneur at $t-1$ would not instead target a lower technology level $B_{t}<\bar{A}_{t}$, which would be less expensive given the assumption that the cost of innovating at a given rate is proportional to the targeted technology level. In Aghion, Howitt, and MayerFoulkes [2004] we answer the question by showing that this alternative would be dominated, from the entrepreneur's point of view, by the strategy of always targeting the frontier. This relies on the fact that the innovation function $\tilde{\mu}(n)$ has an elasticity less than one, which in turn follows from the fact that the innovation cost function $\tilde{n}(\mu)$ is strictly convex with $\tilde{n}(0)=0$. 


\section{II.G. The World Growth Rate}

As in other Schumpeterian models, we suppose that the growth rate $g$ of the global technology frontier is determined by the pace of innovations in the leading countries, none of which are assumed to be credit-constrained. For simplicity, assume that there is just one leader, labeled country 1 . Then

$$
g=\sigma \mu_{1}^{*}=\sigma \frac{\beta_{1} \pi_{1}-\eta_{1}}{\delta_{1}},
$$

where $\sigma>0$ is a spillover coefficient and the subscript 1 indicates a parameter value in country 1 .

\section{Theoretical Implications}

\section{III.A. Three Dynamic Patterns}

In general, the country's technology gap $a_{t}$ will evolve according to the unconstrained dynamical system (7) when $a_{t} \geq \underline{a}(\omega)$ and according to the constrained system (10) when $a_{t}<\underline{a}(\omega)$. Thus,

$$
a_{t+t}=H\left(a_{t}\right) \equiv \min \left\{H_{1}\left(a_{t}\right), H_{2}\left(a_{t}\right)\right\} .
$$

Note that $H_{1}$ is a linear function with positive vertical intercept and a slope between 0 and 1 . Also, ${ }^{20} H_{2}$ is an increasing concave function when $a_{t} \leq \min \{\underline{a}(\omega), 1\}$, with $H_{2}(0)=0$ and

$$
H_{2}^{\prime}(0)=\frac{\omega}{\eta}+\frac{1}{1+g} \text {. }
$$

Countries will fall into three groups, defined by the level of financial development $\omega$. The evolution of the technology gap is illustrated for each case in Figures I-III below.

1. Convergence in growth rate, no marginal effect of financial development.

When financial development is sufficiently high that

$$
n * / a * \leq \omega,
$$

so that $a^{*} \geq \underline{a}(\omega)$, then as shown in Figure I, $a_{t}$ will converge asymptotically to the unconstrained steady state $a^{*}>0$. Per-capita GDP will be given by equation

20. See footnote 15 above. 


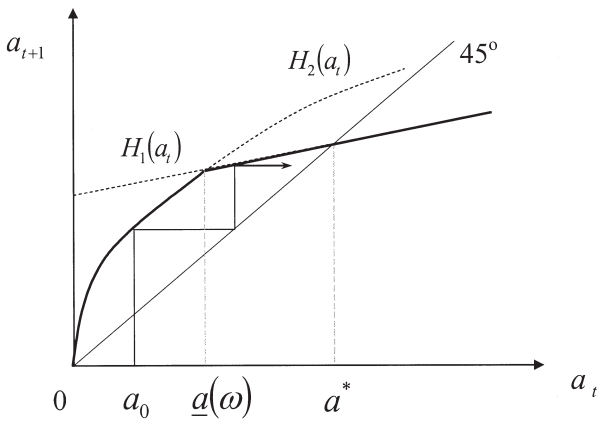

Figure I

A Country with the Highest Level of Financial Development

(8) in the long run, which implies that the country will grow at the same rate $g$ as the global technology frontier in the long run. Increases in financial development will have no marginal effect on either the steady-state growth rate or the steady-state technology gap; these converge, respectively, to the values $g$ and $a^{*}$ which are independent of $\omega .^{21}$

2. Convergence in growth rate with a level-effect of financial development.

When the level of financial development is neither too high nor too low, so that ${ }^{22}$

$$
\frac{\eta g}{1+g} \leq \omega<\frac{n^{*}}{a^{*}},
$$

21. That differences in the credit multiplier $\omega$ within this high financialdevelopment range do not affect the long-run technological gap results from the fact that the incentive constraint underlying $\omega$ (see Appendix 1) only places an upper bound on the amount borrowed by the entrepreneur. As soon as this constraint ceases to bind, then $\omega$ becomes irrelevant in determining the dynamics of productivity. A different model of credit constraints, e.g., one that would rely on ex ante moral-hazard considerations and a continuous effort choice, might generate the possibility that differences in financial development always affect longrun productivity.

22. Note that

$$
\frac{\eta g}{1+g}<\frac{n^{*}}{a^{*}}
$$

because

$$
\frac{\eta g /(1+g)}{n^{*} / a^{*}}=\frac{\eta g \mu^{*}}{n^{*}\left(g+\mu^{*}\right)}<\frac{\eta \mu^{*}}{n^{*}}=\frac{\eta \mu^{*}}{\eta \mu^{*}+\delta\left(\mu^{*}\right)^{2} / 2}<1 .
$$




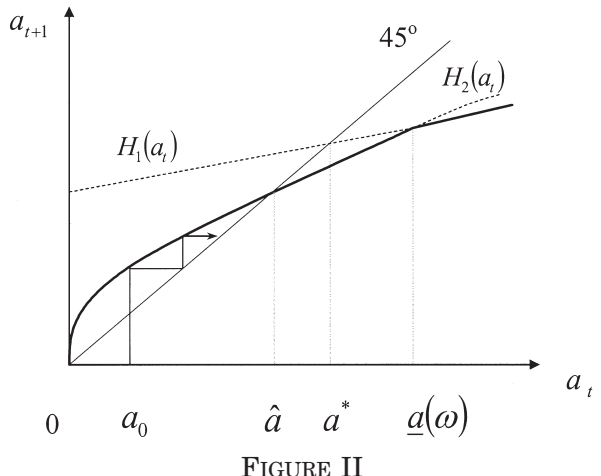

A Country with a Medium Level of Financial Development

then $H\left(a^{*}\right)<H_{1}\left(a^{*}\right)$, so $a_{t}$ cannot converge to the unconstrained steady state $a^{*}$. From (11) we have

$$
H^{\prime}(0)=\frac{\omega}{\eta}+\frac{1}{1+g} \geq \frac{g}{1+g}+\frac{1}{1+g}=1 .
$$

Therefore, as shown in Figure II, $a_{t}$ will converge to a limit $\hat{a}$ that is strictly positive (except in the borderline case where $\eta g /(1+g)=\omega$ and $\hat{a}=0)$ but less than $a^{*}$. In the long run, per-capita GDP will be

$$
\hat{Y}_{t}=[(1-\alpha) \zeta \hat{a}+\tilde{\mu}(\omega \hat{a}) \pi] \bar{A}_{t}<Y_{t}^{*} .
$$

This country will also grow at the rate $g$ in the long run, because $\hat{Y}_{t}$ is strictly proportional to $\bar{A}_{t}$, as is $Y_{t}^{*}$. Increases in financial development will have no marginal effect on the steady-state growth rate, but they will have a positive marginal effect on the steady-state technology gap $\hat{a}$, because they shift the curve $\mathrm{H}_{2}\left(a_{t}\right)$ up in Figure II. ${ }^{23}$ According to (12), increases in financial development will also have a positive effect on the country's steady-state per-capita GDP because of both the direct effect on $\tilde{\mu}$ and the indirect effect working through $\hat{a}$.

23. Formally, from (10),

$$
\frac{\partial a_{t+1}}{\partial \omega}=a_{t} \tilde{\mu}^{\prime}\left(\omega a_{t}\right)\left(1-\frac{a_{t}}{1+g}\right)>0 .
$$


3. Divergence in growth rate, with a growth-effect of financial development.

When the level of financial development is sufficiently low that

$$
\omega<\eta g /(1+g),
$$

then $H\left(a^{*}\right)<H_{1}\left(a^{*}\right)$ and $H^{\prime}(0)<1$, so $a_{t}$ will converge to zero, as shown in Figure III. The following argument shows that in this case the rate of productivity growth, defined as $G_{t}=A_{t+1} / A_{t}-1$, will approach a limiting value that is strictly between 0 and $g$. By l'Hôpital's rule

$$
\lim _{t \rightarrow \infty}\left(\frac{a_{t+1}}{a_{t}}\right)=\lim _{a \rightarrow 0} H^{\prime}(a)=\frac{\omega}{\eta}+\frac{1}{1+g} \in(0,1) .
$$

Therefore,

$$
\lim _{t \rightarrow \infty} G_{t}=(1+g) \lim _{t \rightarrow \infty}\left(\frac{a_{t+1}}{a_{t}}\right)-1=(1+g) \frac{\omega}{\eta} \in(0, g) .
$$

Thus, the steady-state growth rate will be strictly less than the frontier growth rate $g$ and will be strictly increasing in the country's level of financial development. ${ }^{24}$

\section{III.B. Summary}

In summary, the two main implications of our theory are that

1. The likelihood that a country will converge to the frontier growth rate increases with its level of financial development, and

2 . in a country that converges to the frontier growth rate, financial development has a positive but eventually vanishing effect, ceteris paribus, on the steady-state level of per-capita GDP relative to the frontier.

\section{Credit and Convergence: Evidence}

In this section we confront our theoretical predictions with evidence. After describing our data, we test implications 1 and 2 above with a cross-country growth regression involving an interaction term between the log of initial GDP per capita and finan-

24. Aghion, Howitt, and Mayer-Foulkes [2004] show that per-capita GDP grows at the same asymptotic rate as productivity in this case. 


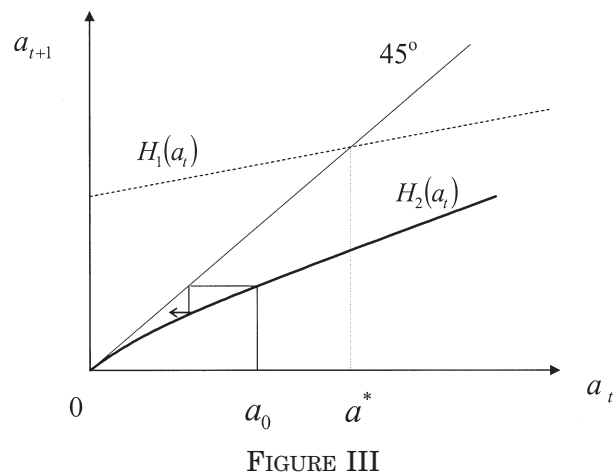

A Country with the Lowest Level of Financial Development

cial development. ${ }^{25}$ This test provides strong evidence for our model and for the general proposition that whether or not a country converges to the frontier growth rate depends on its level of financial development.

\section{IV.A. Data}

We do not have a direct empirical measure of the parameter $v$ or $\omega$ which our theory takes as an indicator of financial development. Instead, we follow the usual practice of using a measure of financial intermediation to proxy for financial development. We analyze cross-sectional data ${ }^{26}$ on 71 countries over the period 1960-1995, taken from Levine, Loayza, and Beck [2000] (LLB) who found a strongly positive and robust effect of financial intermediation on short-run growth in a regression with initial GDP on the right-hand side. We follow LLB in using private credit as our preferred measure of financial development. This is the value of credits by financial intermediaries to the private sector, divided by GDP. It is LLB's preferred measure because it excludes credit granted to the public sector and credit granted by the central

25. We do not pursue a panel-data approach because we believe that financial development is imperfectly measured and persistent, which means that its growth effects are likely to be underestimated by a panel-data approach relative to a cross-section approach [Hauk and Wacziarg 2004]. This may explain why Benhabib and Spiegel [1997, 2000] found no significant interaction between initial GDP and financial development using panel data on 92 countries from 1960 to 1985.

26. See Appendix 2 for a detailed description and sources of data. 


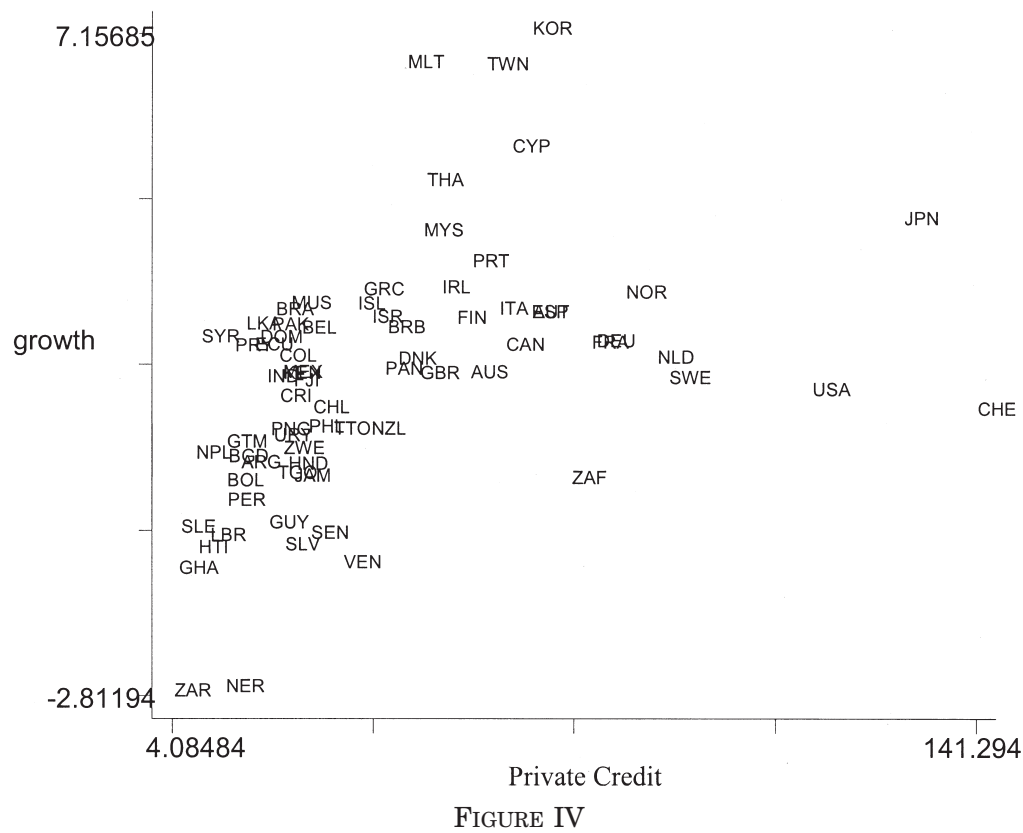

Average Financial Development and Growth Rate of Per-Capita GDP, 1960-1995

bank and development banks. We also report results below using alternative measures.

Figures IV and V show that the raw data are roughly consistent with implications 1 and 2. Figure IV plots the average growth rate of per-capita GDP over the sample period against the average level of financial development over the period. Except for the countries with the three highest growth rates, which are clearly above their steady-state values, the scatter diagram appears consistent with a positive effect of financial development on growth that vanishes at approximately Greece's level of financial development (39 percent), as predicted by the implication 1. Figure $\mathrm{V}$ plots the average log of per-capita GDP on the vertical axis. It appears consistent with a positive effect of financial development on the level of GDP which vanishes once financial development has reached approximately Canada's level (61 percent), as predicted by implication 2 . 


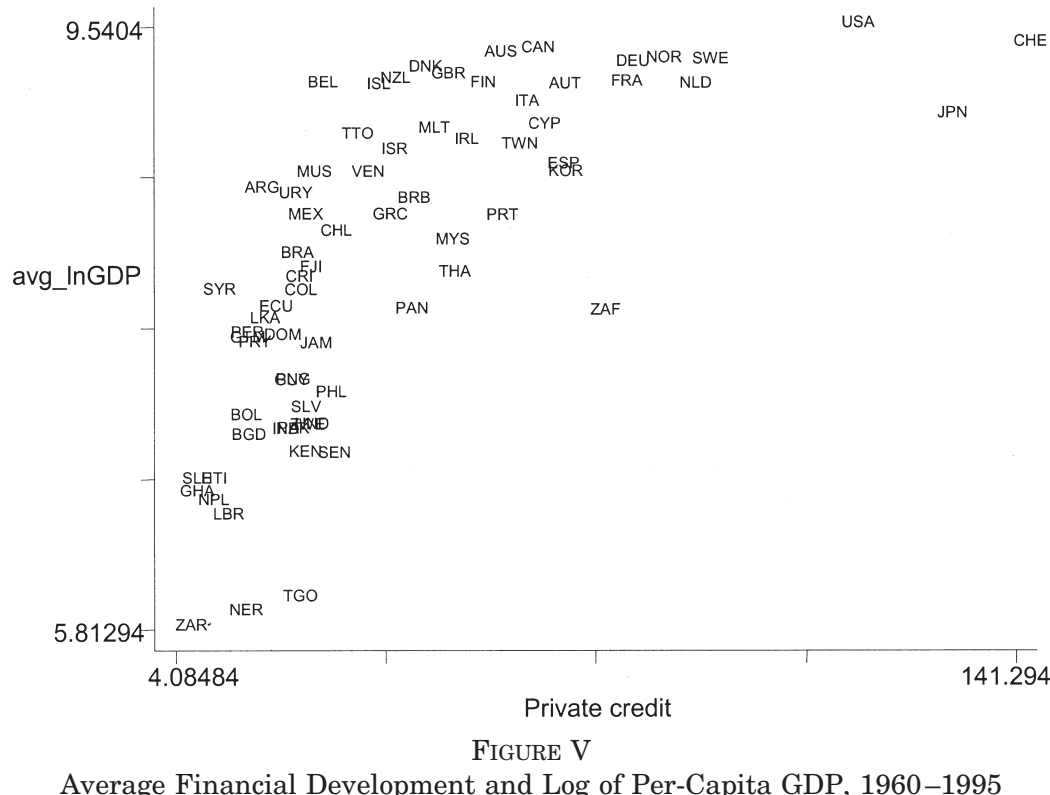

These figures do not control for the effects of initial GDP or any other possible influences on a country's growth path. Nor do they deal with the problem of possible endogeneity of financial development. For these we turn to the following regression results.

IV.B. Growth Regression with an Interaction Term

Our theoretical model can be approximated by the following growth regression: ${ }^{27}$

$$
\begin{aligned}
g_{i}-g_{1}=\beta_{0}+\beta_{f} F_{i}+\beta_{y} \cdot\left(y_{i}-y_{1}\right) & \\
& +\beta_{f y} \cdot F_{i} \cdot\left(y_{i}-y_{1}\right)+\beta_{x} X_{i}+\varepsilon_{i},
\end{aligned}
$$

where $g$ denotes the average growth rate of per-capita GDP, $F$ the average level of financial development, $y$ the initial (1960) log of per-capita GDP, $X$ a set of other regressors and $\varepsilon$ a disturbance

27. See Appendix C of our [2004] working paper for the details of the approximation. 
term with mean zero. Country 1 is the technology leader, which we take to be the United States. This is a standard growth regression except for the interaction term $F_{i} \cdot\left(y_{i}-y_{1}\right)$.

Define $\hat{y}_{i} \equiv y_{i}-y_{1}$, country $i$ 's initial relative per-capita GDP. Under the assumption that $\beta_{y}+\beta_{f y} F_{i} \neq 0$, we can rewrite (13) as

$$
g_{i}-g_{1}=\lambda_{i} \cdot\left(\hat{y}_{i}-\hat{y}_{i}^{*}\right),
$$

where the steady-state value $\hat{y}_{i}^{*}$ is defined by setting the righthand side of (13) to zero:

$$
\hat{y}_{i}^{*}=-\frac{\beta_{0}+\beta_{f} F_{i}+\beta_{x} X_{i}+\varepsilon_{i}}{\beta_{y}+\beta_{f y} F_{i}}
$$

and $\lambda_{i}$ is a country-specific convergence parameter:

$$
\lambda_{i}=\beta_{y}+\beta_{f y} F_{i}
$$

that depends on financial development.

A country can converge to the frontier growth rate if and only if the growth rate of its relative per-capita GDP depends negatively on the initial value $\hat{y}_{i}$; that is, if and only if the convergence parameter $\lambda_{i}$ is negative. Thus, the likelihood of convergence will increase with financial development (implication 1 above) if and only if

$$
\beta_{f y}<0 .
$$

Since this implication constitutes the central proposition of our theoretical model, our main objective in estimating (13) will be to see whether or not the estimated interaction coefficient is indeed significantly negative.

It follows from (14) that the long-run effect of financial development on relative output is

$$
\frac{\partial \hat{y}_{i}^{*}}{\partial F_{i}}=\frac{\beta_{f}+\beta_{f y} \hat{y}_{i}^{*}}{-\left(\beta_{y}+\beta_{f y} F_{i}\right)} .
$$

Assume that all countries lag the United States in steady state: $\hat{y}_{i}^{*} \leq 0$. Then if (16) holds, financial development will have a positive long-run effect on per-capita GDP of each (nonleader) country that converges if and only if $\beta_{f} \geq 0$. For then the numerator of (17) will be positive. Moreover, this effect will eventually vanish (when $F$ reaches the leader's level) if and only if the direct effect is equal to zero:

$$
\beta_{f}=0 .
$$


So if we were to find that (18) held in addition to our main prediction (16), this would corroborate implication 2 . If instead we were to find that $\beta_{f}>0$, then the estimated effect of financial development on $\hat{y}_{i}^{*}$ would never vanish, even for the leader, whereas $\beta_{f}<0$ would imply a negative effect for countries close to the leader.

\section{IV.C. Regression Results}

The financial development variable $F$ in (13) may be endogenous because of feedback from growth to finance, or because of the common effects of omitted variables on both growth and finance. Moreover, endogeneity of $F$ is likely to entail endogeneity of the interaction variable $F \cdot\left(y-y_{1}\right)$. To deal with this problem, we estimated (13) using instrumental variables, instrumenting for $F$ and $F \cdot\left(y-y_{1}\right)$ using legal origins $(L)$ and legal origins interacted with initial relative output $\left(L \cdot\left(y-y_{1}\right)\right)$.

Legal origins is a set of three zero-one variables, used first in the economics literature by La Porta et al. [1997, 1998] and further extended to all 71 countries by LLB, indicating whether the country's legal system is based on French, English, or German traditions (the omitted case is Scandinavian). La Porta et al. argue that the main effect of $L$ is on the rights of investors and creditors. LLB conclude that $L$ constitutes a good set of instruments for financial development because they were established too long ago to suffer from reverse causation, they have a strong effect on financial development and their main effects on growth should be through financial channels. We used the interacted variables $L \cdot\left(y-y_{1}\right)$ as additional instruments to model the interaction term $F \cdot\left(y-y_{1}\right)$, because using $L$ without $L \cdot(y-$ $y_{1}$ ) resulted in too much collinearity between the fitted values of $F$ and $F \cdot\left(y-y_{1}\right)$ to identify the crucial coefficients $\beta_{f}$ and $\beta_{f y}$. We defer further discussion of the instruments until the next section.

Our main results are presented in the first column of Table I, which reports the slope-coefficient estimates for the case where there are no other regressors $X$. These results show that financial development interacted with initial relative output has a significantly negative effect $\left(\beta_{f y}=-0.061<0\right)$, bearing out the main implication of the theory to the effect that convergence depends positively on financial development. They also fail to reject the hypothesis that the direct effect of financial development $\beta_{f}$ is 
TABLE I

Growth, Financial Development, and Initial GDP GaP

Estimation of equation: $g-g_{1}=\beta_{0}+\beta_{f} F+\beta_{y}\left(y-y_{1}\right)+\beta_{f y} F\left(y-y_{1}\right)+\beta_{x} X$

\begin{tabular}{|c|c|c|c|c|c|c|}
\hline \multirow{3}{*}{$\begin{array}{l}\text { Conditioning } \\
\text { set }(X)\end{array}$} & 1 & 2 & 3 & 4 & 5 & 6 \\
\hline & \multicolumn{3}{|c|}{ Private credit } & \multicolumn{3}{|c|}{ Liquid liabilities } \\
\hline & Empty & Policy $^{\mathrm{a}}$ & Full $^{\mathrm{b}}$ & Empty & Policy $^{\mathrm{a}}$ & Full $^{\mathrm{b}}$ \\
\hline \multicolumn{7}{|l|}{$\underline{\text { Coefficient }}$} \\
\hline$\overline{\beta_{f}}$ & $\begin{array}{l}-0.015 \\
(-0.93)\end{array}$ & $\begin{array}{l}-0.013 \\
(-0.68)\end{array}$ & $\begin{array}{l}-0.016 \\
(-0.78)\end{array}$ & $\begin{array}{l}-0.029 \\
(-1.04)\end{array}$ & $\begin{array}{l}-0.030 \\
(-0.99)\end{array}$ & $\begin{array}{l}-0.027 \\
(-0.90)\end{array}$ \\
\hline$\beta_{y}$ & $\begin{array}{l}1.507 \text { *** } \\
(3.14)\end{array}$ & $\begin{array}{l}1.193^{*} \\
(1.86)\end{array}$ & $\begin{array}{c}1.131 \\
(1.49)\end{array}$ & $\begin{array}{l}2.648^{* * * *} \\
(3.12)\end{array}$ & $\begin{array}{l}2.388^{* *} \\
(2.39)\end{array}$ & $\begin{array}{l}2.384^{* *} \\
(2.11)\end{array}$ \\
\hline$\beta_{f y}$ & $\begin{array}{l}-0.061^{* * *} \\
(-5.35)\end{array}$ & $\begin{array}{l}-0.063^{* * *} \\
(-5.10)\end{array}$ & $\begin{array}{l}-0.063^{* * *} \\
(-4.62)\end{array}$ & $\begin{array}{l}-0.076^{* * *} \\
(-3.68)\end{array}$ & $\begin{array}{l}-0.077^{* * * *} \\
(-3.81)\end{array}$ & $\begin{array}{l}-0.073^{* * *} \\
(-3.55)\end{array}$ \\
\hline$\frac{\text { Instrument test }}{\frac{p \text {-values }}{1 \text { st-stage }}}$ & & & & & & \\
\hline $\begin{array}{l}F \text {-test: } F \\
\text { 1st-stage } \\
F \text {-test: }\end{array}$ & 0.0000 & 0.0014 & 0.0024 & 0.0044 & 0.0032 & 0.0042 \\
\hline $\begin{array}{l}F\left(y-y_{1}\right) \\
\text { 1st-stage } \\
F \text {-test: }\end{array}$ & 0.0000 & 0.0000 & 0.0000 & 0.0690 & 0.0078 & 0.0088 \\
\hline$L\left(y-y_{1}\right)$ & 0.0000 & 0.0000 & 0.0001 & 0.0003 & 0.0002 & 0.0022 \\
\hline $\begin{array}{l}\text { Sargan test } \\
C \text {-test for }\end{array}$ & 0.5372 & 0.7255 & 0.5573 & 0.2217 & 0.3952 & 0.3627 \\
\hline $\begin{array}{l}L\left(y-y_{1}\right) \\
C \text {-test for }\end{array}$ & 0.3773 & 0.7013 & 0.4654 & 0.2700 & 0.3549 & 0.2799 \\
\hline$\left(y-y_{1}\right)$ & 0.6475 & 0.7790 & 0.7781 & 0.6240 & 0.6341 & 0.6226 \\
\hline Sample size & 71 & 63 & 63 & 71 & 63 & 63 \\
\hline
\end{tabular}

zero, thus bearing out our theoretical implication of a positive but vanishing steady-state effect. ${ }^{28}$

These findings are significant quantitatively as well as statistically, because they imply that countries will indeed belong to

28. The wide confidence intervals for $\beta_{f}$ are also consistent with a quantitatively large direct effect of financial development, although as pointed out below the point estimate of $\beta_{f}$ indicates that for most converging countries the effect will be quantitatively quite small. 
TABLE I

(CONTINUED)

\begin{tabular}{|c|c|c|c|c|c|}
\hline 7 & 8 & 9 & 10 & 11 & 12 \\
\hline \multicolumn{3}{|c|}{ Bank assets } & \multicolumn{3}{|c|}{ Commercial-central bank } \\
\hline Empty & Policy $^{\mathrm{a}}$ & Full $^{\mathrm{b}}$ & Empty & Policy $^{\mathrm{a}}$ & Full $^{\mathrm{b}}$ \\
\hline-0.019 & -0.020 & -0.022 & 0.000 & 0.031 & 0.013 \\
\hline$(-1.07)$ & $(-1.03)$ & $(-1.12)$ & $(0.00)$ & $(0.17)$ & $(0.07)$ \\
\hline $1.891 * * *$ & $1.335^{*}$ & 1.365 & 7.166 & 5.279 & 5.645 \\
\hline$(3.57)$ & $(1.93)$ & $(1.66)$ & (1.04) & $(0.73)$ & $(0.72)$ \\
\hline$-0.081^{* * *}$ & $-0.081 * * *$ & $-0.081 * * *$ & -0.110 & -0.100 & -0.102 \\
\hline$(-5.07)$ & $(-4.85)$ & $(-4.46)$ & $(-1.29)$ & $(-1.18)$ & $(-1.14)$ \\
\hline 0.0000 & 0.0000 & 0.0000 & 0.2654 & 0.2180 & 0.1704 \\
\hline 0.0010 & 0.0003 & 0.0011 & 0.5160 & 0.2743 & 0.2962 \\
\hline 0.0000 & 0.0000 & 0.0000 & 0.2329 & 0.2315 & 0.4516 \\
\hline 0.8486 & 0.8816 & 0.8279 & 0.9661 & 0.8861 & 0.9223 \\
\hline 0.9940 & 0.9642 & 0.8424 & 0.9482 & 0.7680 & 0.8240 \\
\hline 0.7699 & 0.9944 & 0.9784 & 0.9700 & 0.9818 & 0.9320 \\
\hline 71 & 63 & 63 & 71 & 63 & 63 \\
\hline
\end{tabular}

The dependent variable $g-g_{1}$ is the average growth rate of per-capita real GDP relative to the United States, 1960-1995. $F$ is the average Financial Development $1960-1995$ using four alternative measures, and $y-y_{1}$ is the log of per-capita GDP in 1960 relative to the United States. Appendix 2 gives a detailed description of all variables and indicates sources. Estimation is by IV using $L$ (legal origins) and $L\left(y-y_{1}\right)$ as instruments for $F$ and $F\left(y-y_{1}\right)$. The numbers in parentheses are $t$-statistics. Significance at the 1 percent, 5 percent, and 10 percent level is denoted by $* * *, * *$, and $*$, respectively.

a. The Policy conditioning set includes average years of schooling in 1960 (school), government size (gov), inflation $(p i)$, black market premium ( $b m p$ ), and openness to trade (trade).

b. The Full conditioning set includes the Policy set plus indicators of revolutions and coups (revc), political assassinations (assass), and ethnic diversity (avelf).

different convergence clubs. Specifically, a country can converge to the frontier growth rate if and only if its convergence parameter (15) is negative; that is, if and only if its level of private credit exceeds the critical value

$$
F^{c}=-\beta_{y} / \beta_{f y},
$$

which according to our estimates equals 25 percent. Just over half the countries in our sample (37 of 71) exceed this critical value. 


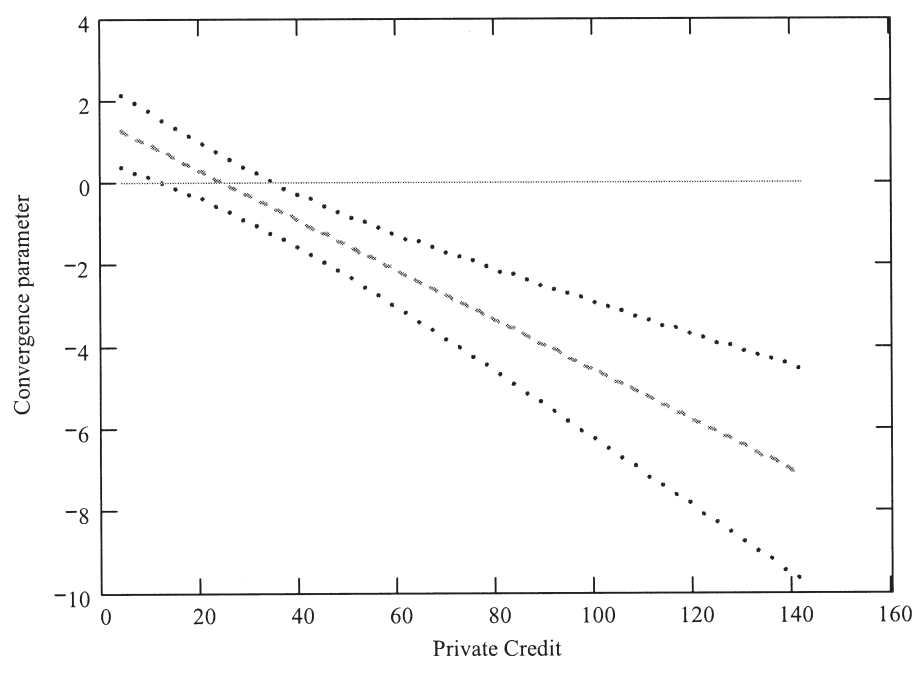

FIGURE VI

Estimated Convergence Parameter over the Observed Range of Private Credit (Positive values imply nonconvergence.)

Figure VI shows the estimated convergence parameter as a function of private credit, over the observed range of $F$, with twostandard-deviation bands. As indicated in Table II, the estimated parameter is at least two standard deviations below zero for 30 countries, the group most likely to converge in growth rate, and two standard deviations above zero for 7 countries, those most likely to diverge. The average estimated convergence parameter in the sample is -0.82 , which implies an annual convergence rate of almost 5 percent.

Another measure of the economic significance of our parameter estimates is the size of the implied effect of financial development on a converging country's steady-state relative output. As predicted by implication 2 of our theoretical analysis, this effect is a diminishing function of financial development. Specifically, a one-standard-deviation increase in private credit (28 percentage points) would raise steady-state GDP by 21 percent in Belgium, the (estimated) converging country with the smallest level of private credit. But the effect would be less than 8 percent in every other converging country, and less than 1 percent for each of the 30 "most likely to converge" countries.

The next two columns of Table I show that our results are robust to the inclusion of other regressors. Specifically, column 2 
TABLE II

Convergence Club Membership

\begin{tabular}{|c|c|c|}
\hline $\begin{array}{c}1 \\
\text { Countries most } \\
\text { likely to } \\
\text { converge in } \\
\text { growth rate }\end{array}$ & $\begin{array}{l}\text { Countries uncertain } \\
\text { to converge in } \\
\text { growth rate }\end{array}$ & $\begin{array}{c}3 \\
\text { Countries most } \\
\text { likely to } \\
\text { diverge in } \\
\text { growth rate }\end{array}$ \\
\hline $\begin{array}{l}\text { Switzerland } \\
\text { Japan } \\
\text { United States } \\
\text { Sweden } \\
\text { Netherlands } \\
\text { Norway } \\
\text { Germany } \\
\text { France } \\
\text { South Africa } \\
\text { Korea } \\
\text { Austria } \\
\text { Spain } \\
\text { Cyprus } \\
\text { Canada } \\
\text { Italy } \\
\text { Taiwan } \\
\text { Portugal } \\
\text { Australia } \\
\text { Finland } \\
\text { Ireland } \\
\text { Thailand } \\
\text { Malaysia } \\
\text { United Kingdom } \\
\text { Malta } \\
\text { Denmark } \\
\text { Barbados } \\
\text { Panama } \\
\text { New Zealand } \\
\text { Israel } \\
\text { Greece }\end{array}$ & $\begin{array}{l}\text { Iceland } \\
\text { Venezuela } \\
\text { Trinidad \& Tobago } \\
\text { Chile } \\
\text { Senegal } \\
\text { Philippines } \\
\text { Belgium* } \\
\text { Jamaica } \\
\text { Mauritius } \\
\text { Honduras } \\
\text { Fiji } \\
\text { Zimbabwe } \\
\text { Mexico } \\
\text { El Salvador } \\
\text { Kenya } \\
\text { Colombia } \\
\text { Togo } \\
\text { Costa Rica } \\
\text { Brazil } \\
\text { Uruguay } \\
\text { Papua New Guinea } \\
\text { Pakistan } \\
\text { Guyana } \\
\text { India } \\
\text { Dominican Republic } \\
\text { Ecuador } \\
\text { Sri Lanka } \\
\text { Argentina } \\
\text { Paraguay } \\
\text { Bangladesh } \\
\text { Peru } \\
\text { Guatemala } \\
\text { Bolivia } \\
\text { Niger }\end{array}$ & $\begin{array}{l}\text { Liberia } \\
\text { Syrian Arab Republic } \\
\text { Nepal } \\
\text { Haiti } \\
\text { Ghana } \\
\text { Sierra Leone } \\
\text { Zaire }\end{array}$ \\
\hline
\end{tabular}

Financial development decreases, and hence the estimated convergence parameter increases, as you move down each list and then to the right. ${ }^{*}$ The estimated convergence parameter is negative (indicating convergence) in countries above (and including) Belgium and positive (indicating divergence) in countries below Belgium. 
uses LLB's policy conditioning set, which includes average years of schooling in 1960, government size, inflation, the black market exchange-rate premium, and openness to trade. Column 3 uses their full conditioning set, which includes the policy conditioning set plus measures of political stability and ethnic diversity. As these two columns indicate, the sign, size, and significance of the crucial coefficients $\beta_{f}$ and $\beta_{f y}$ remain virtually unchanged across alternative conditioning sets.

The remaining columns report the results when three alternative measures of financial development are used. The first is liquid liabilities, which is currency plus demand and interestbearing liabilities of banks and nonbank financial intermediaries, divided by GDP. This is a commonly used measure of financial development, although it includes liabilities backed by credits to the public sector and may involve double counting. The second alternative measure is bank assets, the ratio of all credits by banks (but not other financial intermediaries) to GDP. The third is commercial-central bank, the ratio of commercial bank assets to the sum of commercial plus central bank assets, which has been used by others although it is not so much a measure of financial development as a measure of what fraction of credit is issued by private intermediaries. Our main results $\left(\beta_{f y}<0\right.$ and $\left.\beta_{f}=0\right)$ are robust to all three alternative measures, although in the case of commercial-central bank (our least preferred measure ex ante) the coefficient estimates all lose their statistical significance. As in the case of private credit, in all three cases the sign, size, and significance of the crucial coefficients $\beta_{f}$ and $\beta_{f y}$ remain virtually unchanged across alternative conditioning sets. ${ }^{29}$

We checked the robustness of our results against outliers by removing all countries with a residual more than three standard deviations from zero and then reestimating. We also did this using two standard deviations instead of three. We did this for each of the first nine cases in Table I. The coefficient $\beta_{f y}$ never changed sign, and its statistical significance was always even larger than reported in Table I, while $\beta_{f}$ was never significantly different from zero. Thus, it seems that the results reported in Table I are not driven by outliers.

29. Although our theory does not rule out nonfinancial determinants of steady-state output and growth, the fact that our estimated effects of financial development are independent of other conditioning variables suggests that we can safely treat the influence of those other determinants as part of the error term in the equations with empty conditioning sets. 


\section{IV.D. Instruments}

We tested the strength of our instruments with the usual $F$-tests of joint significance in the first-stage regressions of $F$ and $F \cdot\left(y-y_{1}\right)$. The $p$-values reported in the first two rows of the lower panel of Table I indicate that the instruments passed this test at the 1 percent level in all three equations involving private credit, our preferred measure of financial development, in all equations involving bank assets and in all but one involving liquid liabilities. The instruments passed at the 10 percent significance level in all equations not involving commercial-central bank. Because of our a priori doubts as to the suitability of the commercial-central bank measure, we believe that the other three measures are telling us the right message.

These results confirm and extend similar findings by LLB. However, we have added to their analysis the three interacted instruments $L \cdot\left(y-y_{1}\right)$, and it is important that they have additional explanatory power. Accordingly, the third row of the lower panel of Table I reports the $p$-value of an $F$-test of the hypothesis that all three interacted instruments are insignificant in both first-stage regressions. The hypothesis is rejected at the 1 percent level in all equations except those using the suspect commercial-central bank measure. Thus, our addition of the interacted instruments does not appear to have created a "manyinstruments" problem.

From here on we omit the commercial-central bank measure from our analysis, on the grounds that for our purposes it is a priori inferior to the other measures and behaves empirically very differently from the others.

To be valid, our legal-origins instruments must not affect growth through any channel other than finance, since otherwise the effects we are attributing to finance might actually be effects of these nonfinancial channels. This restriction might appear questionable because, for example, different legal systems could result in different regulatory environments that affect barriers to entry as argued by Djankov et al. [2000]. Therefore, we tested the restriction using the standard Sargan test, whose null hypothesis is that the instruments are uncorrelated with the IV residuals. If our instruments were affecting growth through an omitted nonfinancial variable, then the Sargan test should reject the null. However, the large $p$-values reported in the fourth row of the 
lower panel of Table I show that the instruments pass the test in all cases.

Again, these results confirm and extend the findings of LLB with respect to the three main instruments $L$. We tested the specific validity of our interacted instruments $L \cdot\left(y-y_{1}\right)$ with a $C$-test. The large $p$-values in the fifth row of the lower panel of Table I indicate that the instruments pass this test in all cases. The large $p$-values in the sixth row indicated that we also cannot reject the exogeneity of initial relative income.

Another way to test for instrument validity is to include in the equation those variables that represent the alternative nonfinancial channels through which the instruments might affect growth. If these nonfinancial channels are at work, then the new regressors should rob our financial variables of explanatory power. To some extent, the results of Table I already constitute such a test, but the conditioning sets there do not include any interaction terms between the extra regressors and initial relative output. So they leave open the possibility that our main result, the strong negative effect on growth of the interaction between financial development and initial relative output, is coming from the explanatory power of the interacted instruments $L$. $\left(y-y_{1}\right)$ and that this explanatory power derives from correlation between the interacted instruments and some omitted interacted variable.

Table V provides strong evidence that this theoretical possibility is not what is driving our results. As we explain in more detail below, Table $\mathrm{V}$ reports the estimates that result from including each of a long list of alternative regressors, including one that measures regulatory entry barriers, both directly and interacted with initial relative output. But in no case does the inclusion affect our main results, and in no case does the alternative regressor or its interaction have significant explanatory power. If our legal-origins instruments are working through some nonfinancial channel, then it must be one that cannot be measured or has not been brought to our attention.

Our final check on instrument validity was to reestimate Table I using alternative instruments. Specifically, we used the log of settler mortality, which Acemoglu, Johnson, and Robinson [2001] have argued is a good instrument for modern institutions in formerly colonized countries. To model the interacted financial development variable, we also used the log of settler mortality 
interacted with initial relative output as a second instrument. The results are displayed in Table III.

This reestimation produces support for our main hypotheses $\left(\beta_{f y}<0\right.$ and $\left.\beta_{f}=0\right)$, because the estimated $\beta_{f y}$ is always negative and the estimate of $\beta_{f}$ is always statistically indistinguishable from zero. The statistical significance of $\beta_{f y}$ is generally much lower than in Table I, but we attribute this largely to the smaller sample size. Data on settler mortality are available only for 41 ex-colonies in our 71-country data set.

We prefer to work mainly with our legal-origins instruments rather than settler mortality because we do not want to throw 30 countries out of our data set and because in this data set the settler mortality instruments have relatively little explanatory power for the two financial development variables, as indicated by the large $p$-values of the first-stage $F$-tests in the lower panel of Table III, especially when there is a nonempty set of conditioning variables. ${ }^{30}$

In summary, we believe that the effects of financial development on convergence that we find empirically are not artifacts of our use of legal-origins instruments, because the instruments pass standard statistical tests, the effects are robust to controlling for alternative channels through which legal origins might influence growth, and to the extent that data limitations permit, we have reproduced our main results using alternative instruments. ${ }^{31}$

\section{IV.E. Productivity}

As a further test of our theory, we examined whether the effects of $F$ and $F \cdot\left(y-y_{1}\right)$ on per-capita GDP growth were work through productivity growth, as implied by the theory, instead of working just through capital accumulation. ${ }^{32}$ Specifically, we reestimated the basic growth equation (13) using productivity

30. Beck, Demirgüç-Kunt, and Levine [2003] and Acemoglu and Johnson [2003] find that settler mortality is a stronger instrument than legal origins for financial development. This may be partly because they do not include in their equations initial GDP, which in our analysis robs settler mortality of much of its explanatory power.

31. We found the same results using as instruments the initial (1960) value $F_{0}$ of financial development and $F_{0} \cdot\left(y-y_{1}\right)$. The only exception was the case using liquid liabilities with the full conditioning set, where the $p$-value of the interaction coefficient rose to 0.12 .

32. Our procedure follows closely that of King and Levine [1993a] and Beck, Levine, and Loayza [2000], who used a similar framework without the interaction terms. 


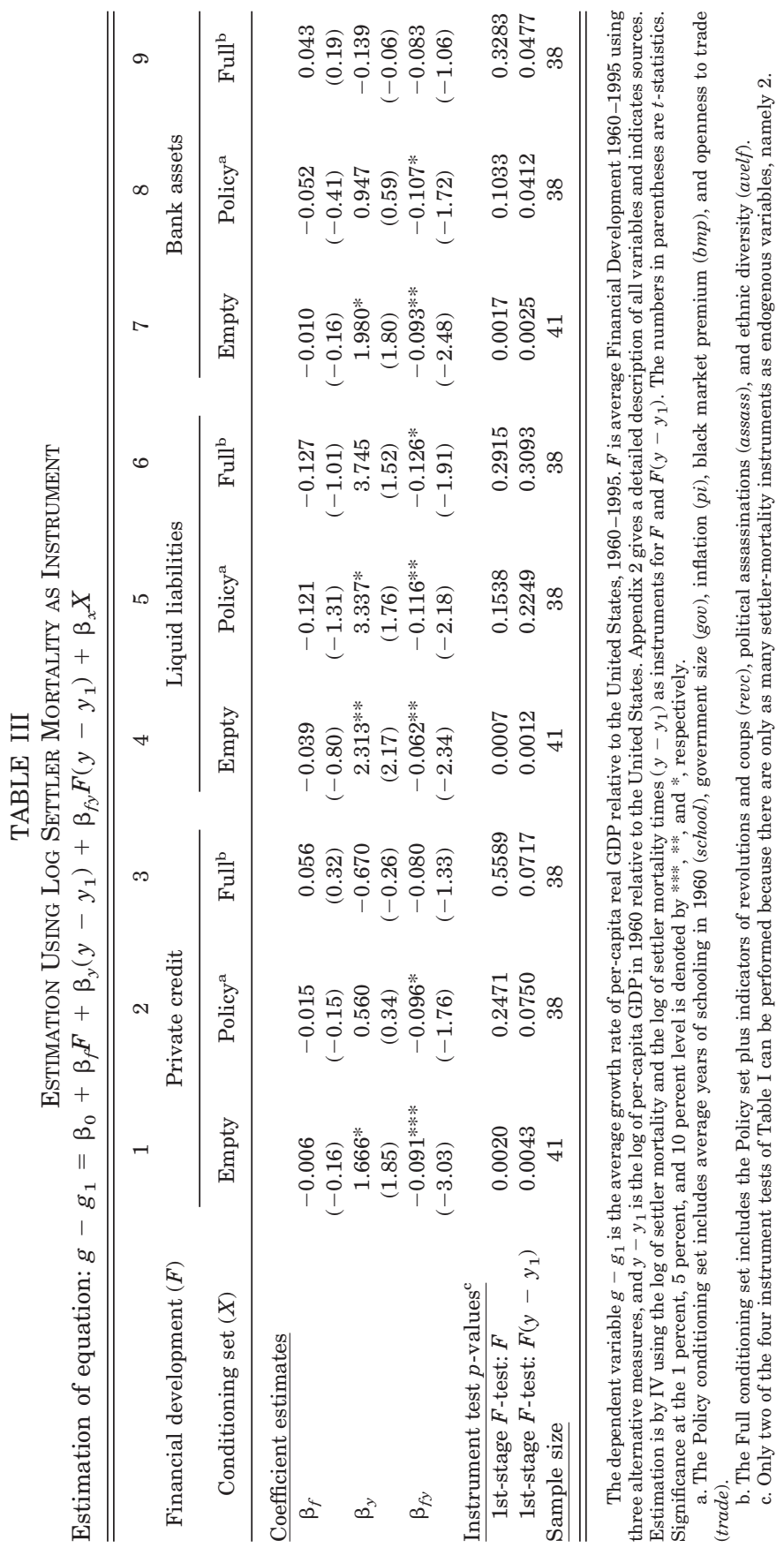


growth as the dependent variable instead of growth in per-capita GDP, and interpreting $y$ as the log of aggregate productivity in 1960 instead of the log of per-capita GDP. We took our productivity variable from Benhabib and Spiegel [2005]. The results are presented in Table IV.

These results are similar to what we obtained using percapita GDP. Specifically, the crucial interaction coefficient $\beta_{f a}$ is still negative and significant at the 1 percent level in all equations, with magnitudes similar to Table I. Also the coefficient $\beta_{f}$ of $F$ remains not significantly different from zero, except in the case of specification 4, where it is significant at the 10 percent level. As before, the results are stable across conditioning sets, and our legal-origins instruments continue to pass the tests for strength and validity.

\section{IV.F. Alternative Explanations of Divergence}

Perhaps what prevents poor countries from converging in growth rate is not lack of financial development but lack of education, or perhaps financial development matters for growth only because it facilitates investment in schooling, as in Galor and Zeira [1993]. Or maybe divergence is explained by some other variable that is associated with a low initial level of GDP, or with a low level of private credit. ${ }^{33}$ Table $\mathrm{V}$ addresses these questions by checking whether the effect of finance on convergence is robust to including a possible effect of initial relative output, schooling, or a host of other variables on convergence.

Specifically, we included as an additional regressor the square of initial relative output, $\left(y-y_{1}\right)^{2}$. If this term were to have a significant negative coefficient $\beta_{y y}$, it might indicate that what keeps poor countries from joining the convergence club is just being poor to start with, or something other than finance that is correlated with being poor to start with. Next we included as additional regressors not $\left(y-y_{1}\right)^{2}$ but the variable schoolaverage years of schooling in 1960 -and also the interaction term school $\cdot\left(y-y_{1}\right)$. If the latter were to have a significant negative coefficient, it might indicate that lack of education is what keeps

33. Another interpretation of our finding of a negative interaction coefficient $\beta_{f y}$ is that entrepreneurs in poor countries have relatively few alternatives to borrowing from financial intermediaries because of weak or nonexistent equity and bond markets. To the extent that weak equity and bond markets are a by-product of weak investor protection, the same factor that our theory is focusing on, this alternative interpretation is complementary with ours. 


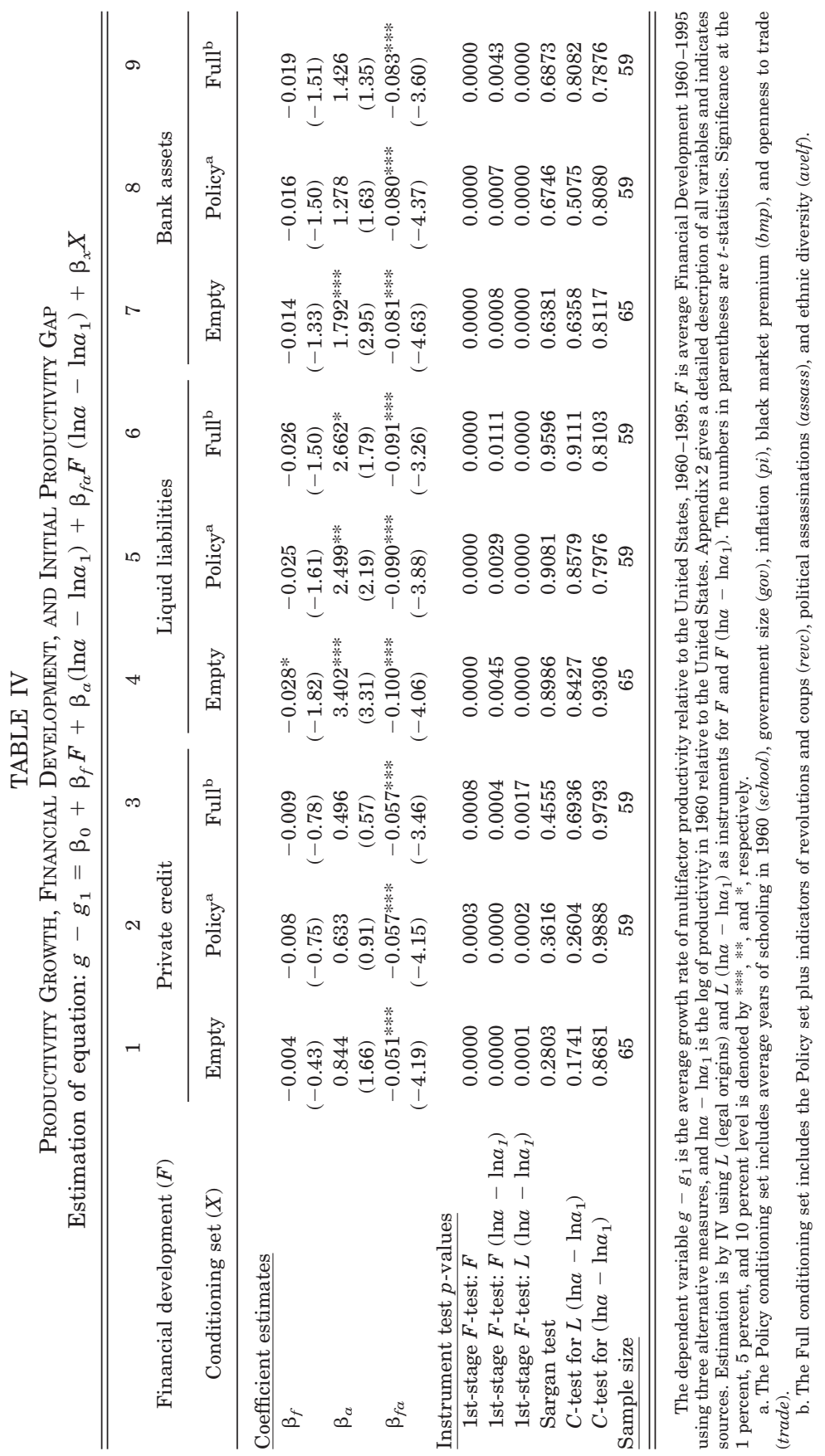


poor countries from joining the convergence club, for the same reason that a negative interaction effect with financial development indicates that lack of finance is what keeps them from converging. We repeated the same procedure with 31 other variables that have been suggested in the literature. These include alternative schooling variables, geographical variables, variables measuring population health, policy variables, variables indexing the degree of sociopolitical stability, and a list of eleven institutional variables.

If our results were fragile, if the main determinant of convergence were not financial development but something else that was just correlated with financial development, or if our legal instruments were working on growth and convergence primarily through some channel other than financial development, then the addition of at least some of these variables and their interaction with initial relative output should destroy the explanatory power of $F \cdot\left(y-y_{1}\right)$ in our growth regression, or make the coefficient $\beta_{f}$ on $F$ significantly different from zero. But the results of Table $\mathrm{V}$ show otherwise. The estimated sign of the coefficient $\beta_{f y}$ remains negative in all cases, and statistically significant in all cases except when the alternative variable is settler mortality, a case in which, as mentioned above, the number of observations is very small. ${ }^{34}$

According to Table $\mathrm{V}$, in all cases the coefficient $\beta_{f}$ of $F$ remains not significantly different from zero when these alternative variables are included in the regression. Moreover, in no case was the interaction between an alternative variable and initial relative output statistically significant. The lower panel of Table $\mathrm{V}$ indicates that our instruments remained strong and that they continued to pass the Sargan test.

To guard against the possibility that these results are an artifact of some powerful but unexplained effect of the interacted legal-origins instruments on growth, we redid all the estimations of Table V using OLS. This reestimation again confirmed our

34. We explored this single exception further by pooling the 41 ex-colonies with the others. We set settler mortality equal to the New Zealand value (the lowest in the data) for all non-ex-colonies and included in the regression a dummy for non-ex-colony and an interaction between this dummy and initial relative output. This formulation assumes that being an ex-colony has an effect on growth and convergence but not on the growth effects of having more financial development. The results are displayed in the last column of Table V. They confirm our main predictions, and suggest that the only exception in Table $\mathrm{V}$ to the finding of a significantly negative interaction coefficient may indeed be attributable to a small sample size. 


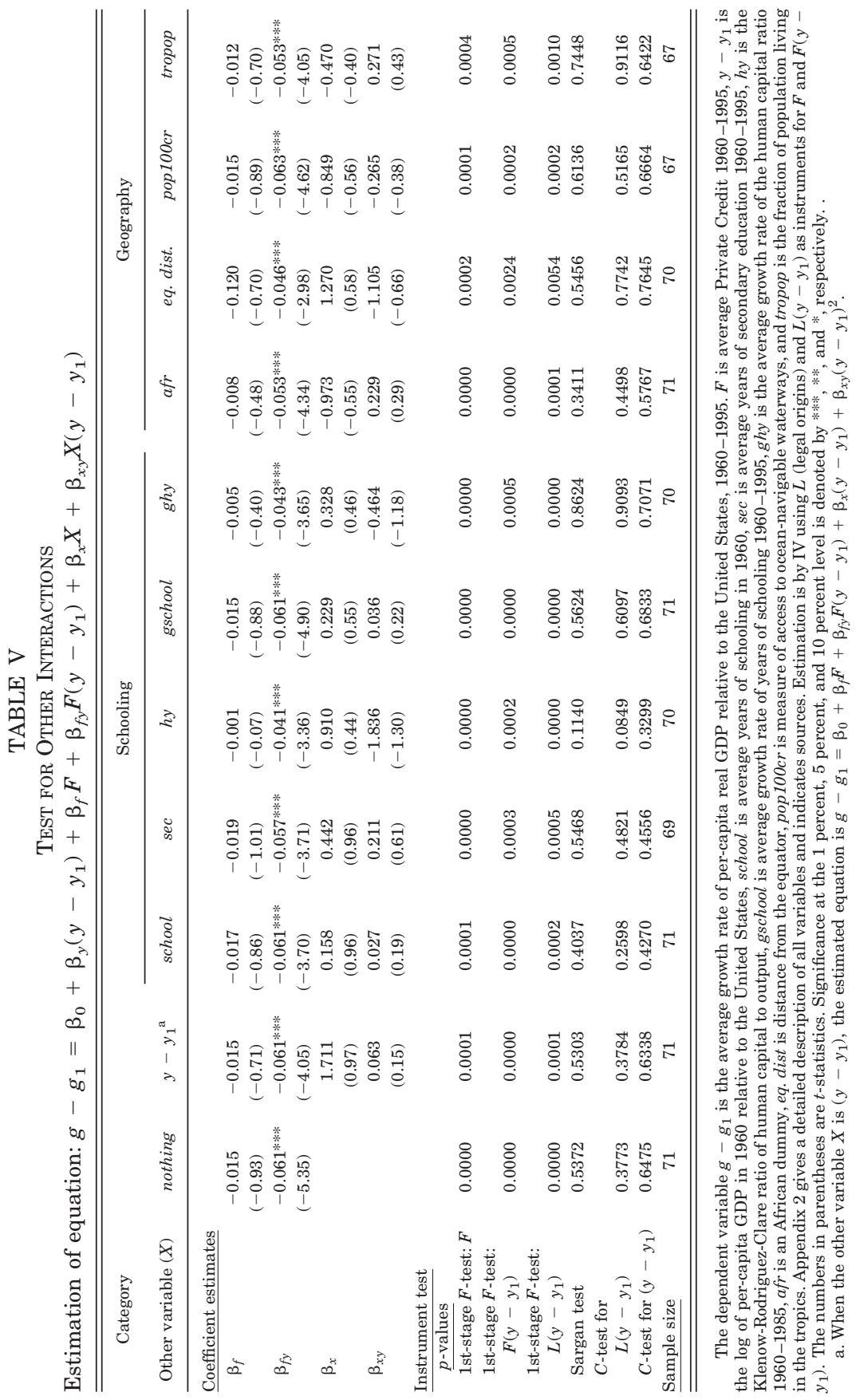




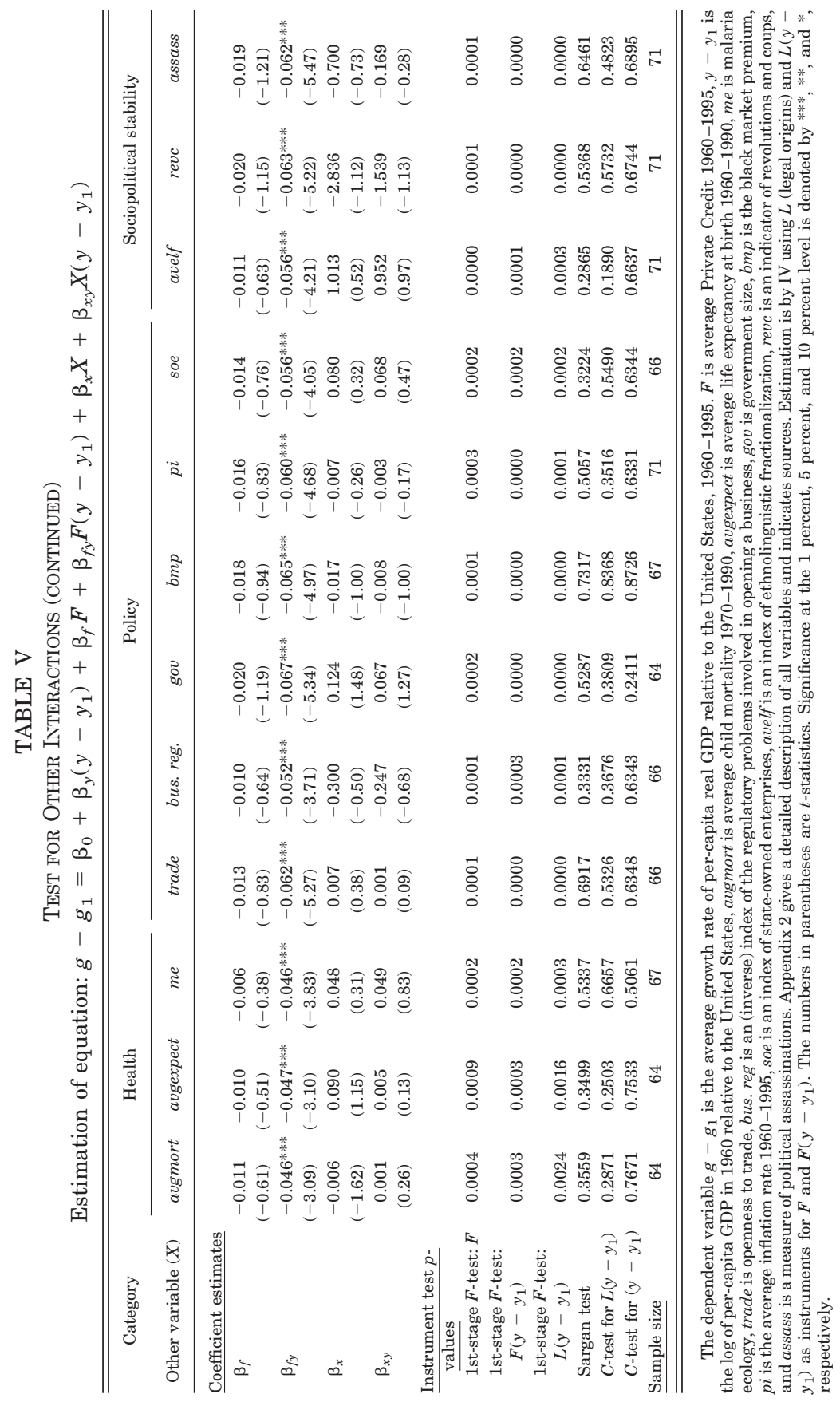




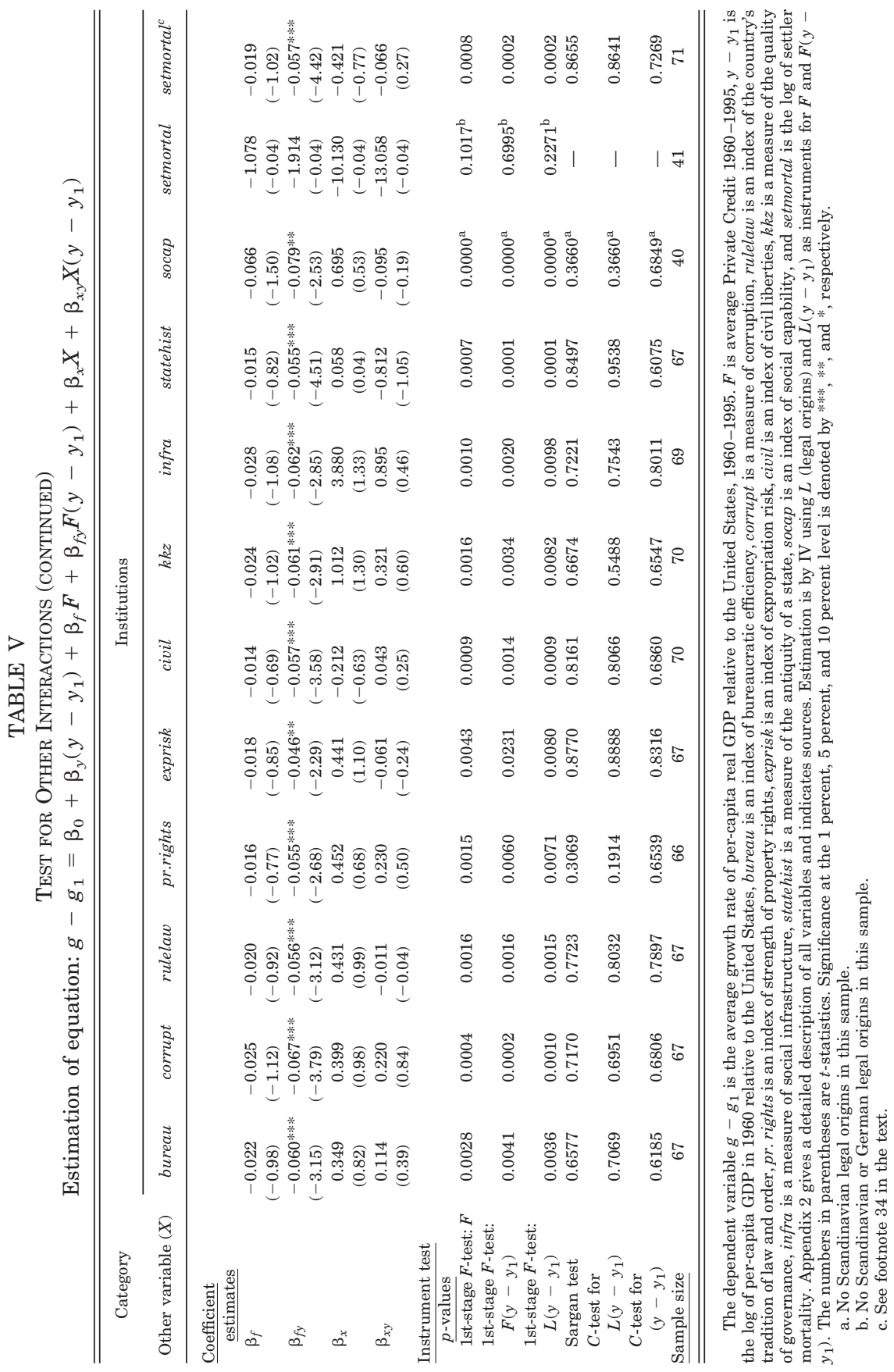


main theoretical results; the coefficient $\beta_{f}$ on $F$ was never significantly different from zero, and the interaction coefficient $\beta_{f y}$ in all cases was negative and statistically significant except when the alternative variable was settler mortality.

To the same end, and also to take into account the possibility that some of the alternative regressors $X$ are endogenous to the growth regression, we followed the suggestion of an anonymous referee to reestimate Table $\mathrm{V}$ instrumenting for the $X$ 's and the interacted $X \cdot\left(y-y_{1}\right)$ variables instead of for private credit and private credit interacted. If the interaction coefficient $\beta_{f y}$ were to lose its significance and the coefficient of some $X \cdot\left(y-y_{1}\right)$ were to show up as significant in this "switched" IV regression, this would suggest that the effects we have been attributing to the interaction between finance and the initial GDP gap were really attributable to the effect of our legal origins instruments working through some channel other than finance.

The results shown in Table VI indicate that our earlier findings pass this test. In only one case (state history) is the coefficient of the interaction variable $X \cdot\left(y-y_{1}\right)$ significant at the 10 percent level in the switched IV regression, and in that case the critical interaction coefficient $\beta_{f y}$ retained its significance at the 1 percent level. Although in several other cases $\beta_{f y}$ lost its statistical significance, this only happened when our legal origins instruments turned out to have little explanatory power in the first-stage regressions for $X \cdot\left(y-y_{1}\right)$, being jointly insignificant at the 10 percent level; since weak instruments are known to produce unreliable and imprecise IV estimate ${ }^{35}$ we do not interpret this loss of significance as casting doubt on our theoretical predictions. However, it does perhaps provide a clue for understanding our otherwise surprisingly robust results.

More specifically, most of the loss in significance of $\beta_{f y}$ in Table VI occurs when $X$ represents an institutional variable. ${ }^{36}$ This is probably because the interacted forms of these variables, and especially their fitted values from the first-stage regression, are highly correlated with the interacted private credit variable (see columns 2 and 3, Table VII), which makes it hard econometrically to identify their effects on growth separately from those of

35. See, for example, Davidson and MacKinnon [2004, p. 329].

36. Specifically, our main predictions (insignificant $\beta_{f}$ and significantly negative $\beta_{f y}$ ) were confirmed in the case of 18 of the 22 noninstitutional variables but only in 3 of the 11 institutional variables. 


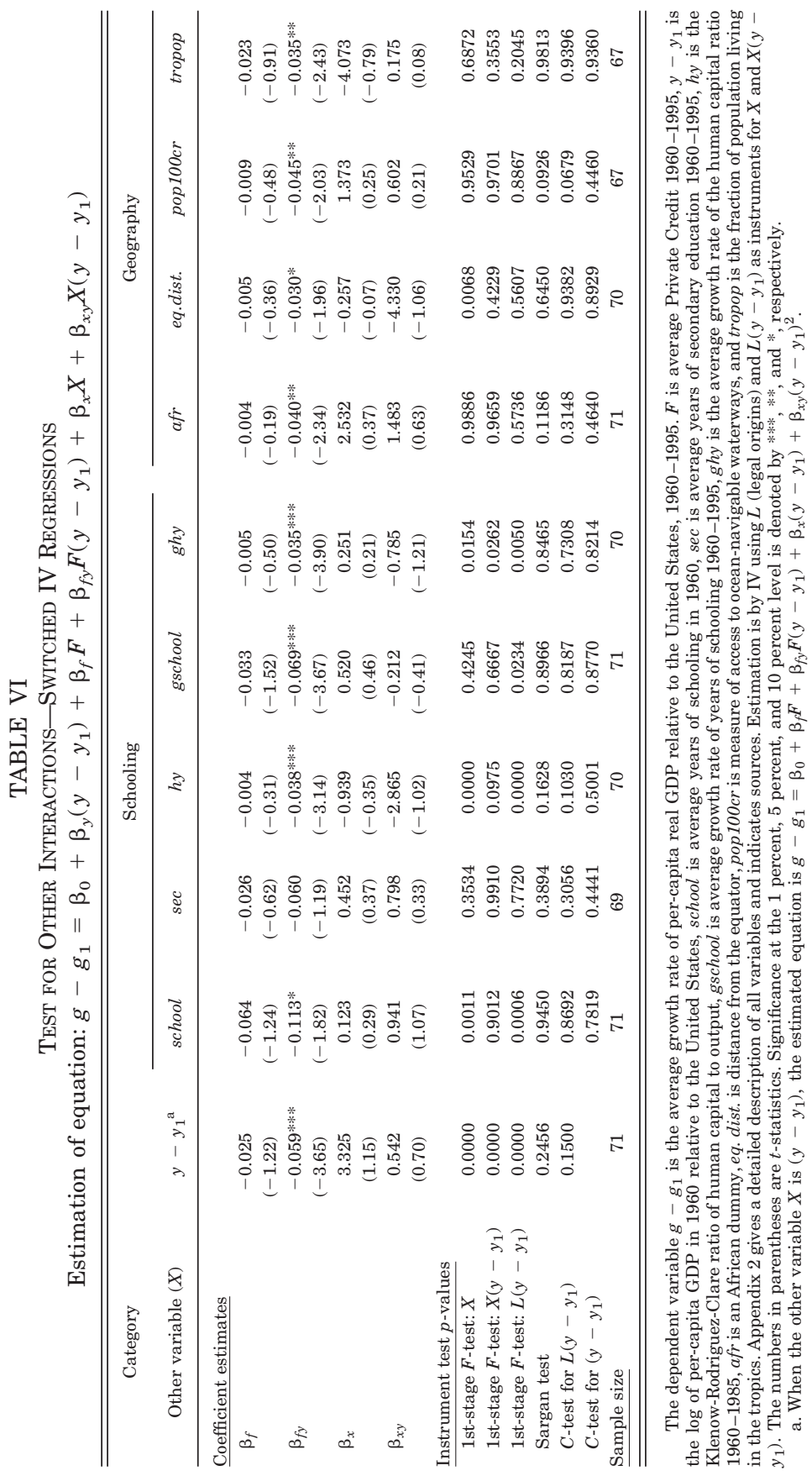




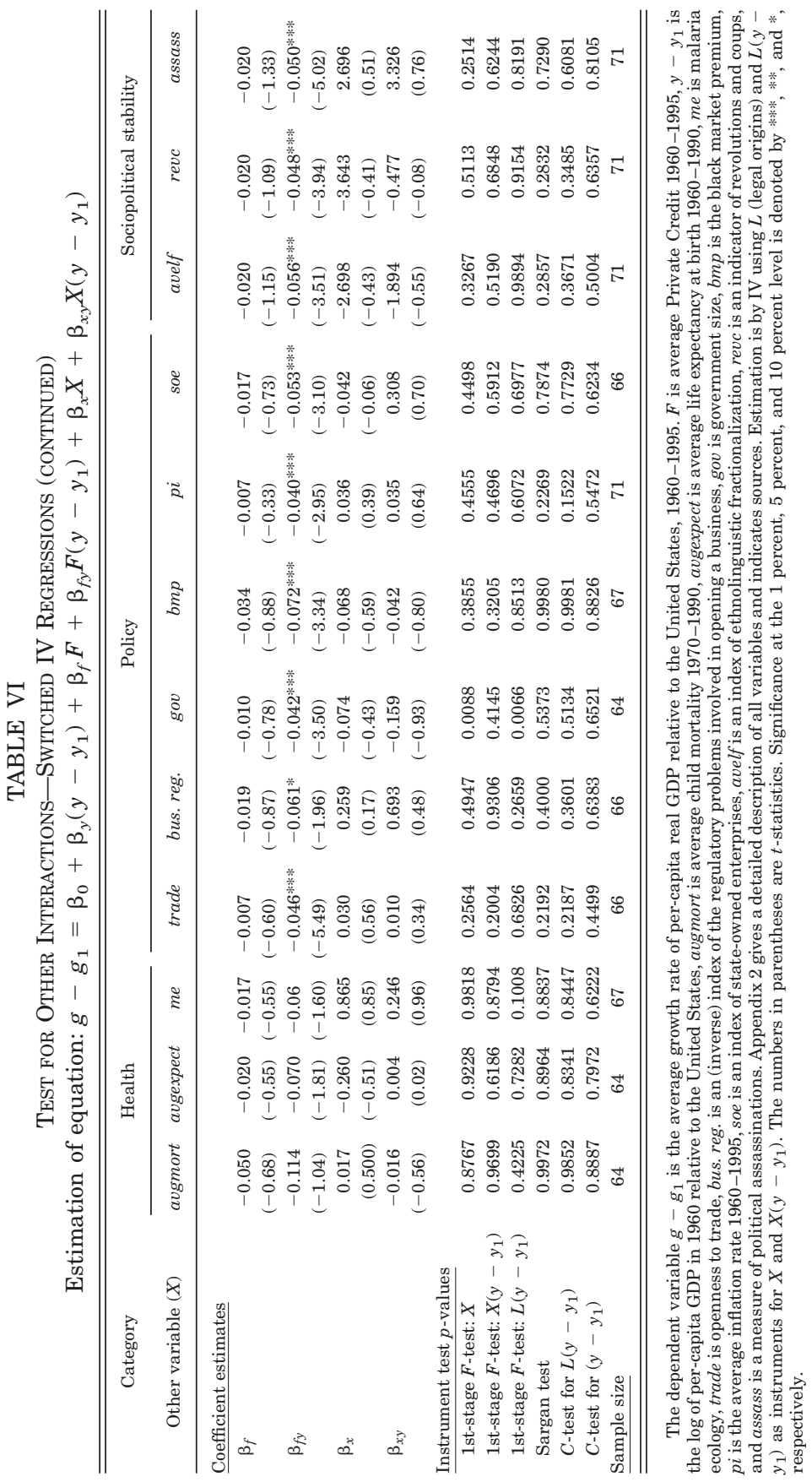




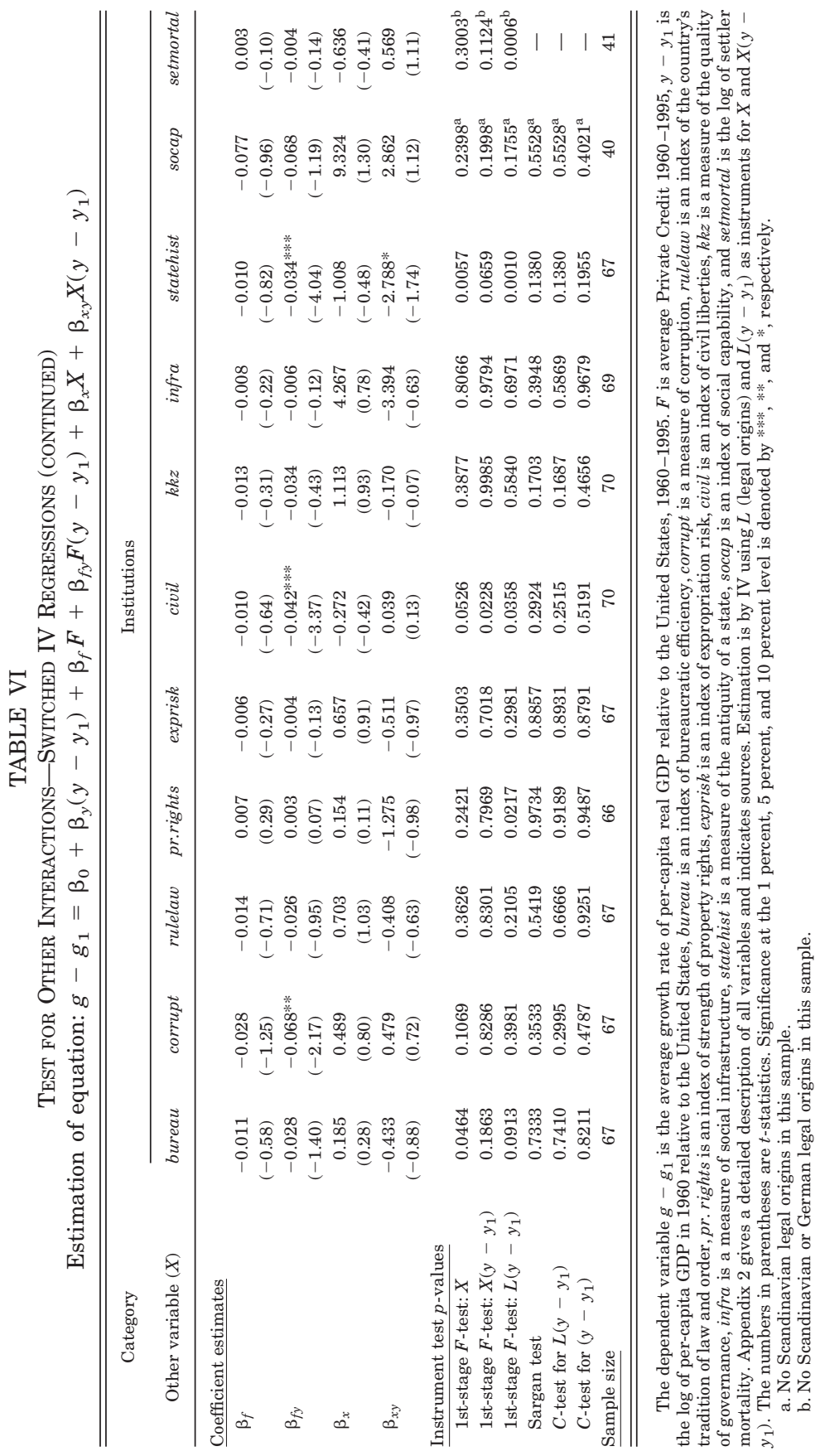


TABLE VII

PRIVAte CRedit and Other Institutional Variables

\begin{tabular}{|c|c|c|c|c|}
\hline Variable & $\begin{array}{c}\text { Correlation } \\
\text { between } X \\
\text { and } F\end{array}$ & $\begin{array}{c}\text { Correlation } \\
\text { between } \\
X\left(y-y_{1}\right) \\
\text { and } F(y- \\
\left.y_{1}\right)\end{array}$ & $\begin{array}{l}\text { Correlation } \\
\text { between } \\
\text { fitted } X(y \\
\left.-y_{1}\right) \text { and } \\
F\left(y-y_{1}\right) \\
\text { in switched } \\
\text { regression }\end{array}$ & $\begin{array}{l}P \text {-value of } F \text {-test } \\
\text { for joint } \\
\text { significance of } \\
X\left(y-y_{1}\right) \text { and } \\
F\left(y-y_{1}\right) \text { in } \\
\text { switched } \\
\text { regression }\end{array}$ \\
\hline & 1 & 2 & 3 & 4 \\
\hline bureau & 0.7325 & 0.6752 & 0.7872 & 0.0000 \\
\hline corrupt & 0.7053 & 0.6663 & 0.8303 & 0.0000 \\
\hline rulelaw & 0.7138 & 0.6656 & 0.7996 & 0.0000 \\
\hline pr.rights & 0.6273 & 0.5786 & 0.6491 & 0.0434 \\
\hline exprisk & 0.7552 & 0.6032 & 0.6140 & 0.0272 \\
\hline civil & -0.5701 & 0.1233 & 0.1819 & 0.0000 \\
\hline$k k z$ & 0.7251 & 0.3185 & 0.4051 & 0.0014 \\
\hline infra & 0.7318 & 0.7130 & 0.9025 & 0.0165 \\
\hline statehist & 0.4924 & 0.4716 & 0.6091 & 0.0000 \\
\hline socap & 0.4399 & 0.3055 & 0.1831 & 0.3581 \\
\hline setmortal & -0.6375 & 0.2052 & 0.0782 & 0.3111 \\
\hline
\end{tabular}

the interacted private credit variable. ${ }^{37}$ This interpretation is supported by the fact that in all but two cases with a relatively small sample size we can reject the hypothesis that both interacted variables have a zero effect at the 5 percent significance level using the switched regression results (see column 4, Table VII). But it leaves open the possibility that what really matters for convergence is some unspecified combination of financial development and other institutions, and that the effects of other institutions have not shown up in the above results because of our inability to find appropriate instruments to correct for their endogeneity. ${ }^{38}$

Overall, we interpret the results of this section as further evidence to the effect that lack of financial development accounts

37. This is not independent of the weak instrument problem. When the legal origins instruments have little explanatory power, the fitted value of $X \cdot\left(y-y_{1}\right)$ is just a noisy linear combination of the other" "exogenous" regressors in the growth equation, including $F \cdot\left(y-y_{1}\right)$.

38. For example, perhaps what matters most for convergence is wellfunctioning markets, for which many institutional variables are a good indicator but none better than financial development. We have tried exploring the issue further by instrumenting in the same equation for $X, X \cdot\left(y-y_{1}\right), F$ and $F \cdot(y-$ $\left.y_{1}\right)$ but our inability to find strong instruments for $X$ and $X \cdot\left(y-y_{1}\right)$ has prevented us from shedding any further light on the question. 
for the failure of some countries to converge to the growth rate of the global technology frontier, a further corroboration of our theory, and a further indication of the validity of our legal-origins instruments for financial development. But we cannot rule out the possibility that at least some of the failure to converge is also attributable to institutional factors other than finance, or to some other variable that is also endogenous to the growth process.

\section{Conclusion}

The paper has developed and tested a Schumpeterian model of cross-country convergence with financial constraints. The model is consistent with the broad facts of convergence and divergence since the early nineteenth century. It implies that all countries above some critical level of financial development should converge in growth rate, and that in such countries financial development has a positive but eventually vanishing effect on steady-state GDP. These implications were tested by estimating a cross-country growth regression with an interaction term between financial development and the country's initial relative output. As predicted, the coefficient of this interaction term is negative and highly significant, and the direct effect of financial development is not significantly different from zero.

Why some countries fail to converge in growth rates despite the possibility of technology transfer has been a puzzle. In combination with the contributions of Howitt [2000], Acemoglu, Aghion, and Zilibotti [2002], and Howitt and Mayer-Foulkes [2002] our theoretical results show that Schumpeterian growth theory provides a framework for analyzing a variety of forces that contribute to nonconvergence. ${ }^{39}$ Our empirical results suggest that financial development is among the most powerful of these forces, especially considering that educational attainment, initial relative output, and a large number of other candidate variables do not have an analogous effect when included in the same regression with financial development. ${ }^{40}$

39. See Galor and Weil [2000], Gollin, Parente, and Rogerson [2002], and Hansen and Prescott [2002] for alternative theories of convergence and divergence based on the transition from agricultural to industrial technologies.

40. Our results also suggest that a country might escape divergence by using foreign direct investment as a substitute for lending to local entrepreneurs. However, the results of Alfaro et al. [2003] indicate that foreign direct investment and local finance are complements. Specifically, they find that foreign direct investment has a significant effect on growth only when interacted with finance. 


\section{Appendix 1: Endogenizing the CRedit Multiplier}

This Appendix closely follows Aghion, Banerjee, and Piketty [1999] in deriving a constant credit multiplier from ex post enforcement considerations. More precisely, suppose that at a nonmonetary cost $c N_{t}$ an entrepreneur can hide the result of a successful innovation and thereby avoid repaying her creditors, where $0<c<1$. This cost is an indicator of the degree of creditor protection. In countries where laws and institutions make fraud a costly option, creditors are better protected, and therefore, as we shall see, credit is more readily available to entrepreneurs.

The entrepreneur must pay the hiding cost at the beginning of the period, when she decides whether or not to be dishonest. She will do so when it is in her self-interest, namely when the following incentive-compatibility constraint is violated:

$$
\mu \beta \pi \bar{A}_{t+1}-c N_{t} \leq \mu \beta \pi \bar{A}_{t+1}-\mu R \cdot\left(N_{t}-w_{t}\right),
$$

where $R$ is the interest factor on the loan, $N_{t}-w_{t}$ is the size of the loan, and

$$
\mu=\tilde{\mu}\left(N_{t} / \bar{A}_{t+1}\right)
$$

is the innovation probability. The left-hand side of (19) is the expected payoff from deciding to be dishonest when investing at the rate $N_{t}$, whereas the right-hand side is the expected payoff from deciding to be honest. (If she does not successfully innovate, her payoff is zero, because having invested all her wealth in the unsuccessful project she cannot be made to repay anything.)

The only potential lenders in this OLG model are other young people, who will lend only if offered an expected rate of return equal to $r \equiv \beta^{-1}-1$. Thus, the interest factor on the loan in equilibrium must satisfy not only the incentive-compatibility condition (19) but also the arbitrage condition

$$
\mu R=1+r,
$$

so that the incentive-compatibility condition boils down to an upper limit on the entrepreneur's investment:

This is consistent with the view that foreign direct investment results in technology transfer only when complemented by the local entrepreneurial investments at the heart of our theory, which investments are impeded by lack of financial development. 


$$
N_{t} \leq \frac{1+r}{1+r-c} w_{t}=v w_{t},
$$

where

$$
1<v<\infty .
$$

\section{Appendix 2: Sources and Description of Data}

setmortal: Log of European settler mortality, Acemoglu, Johnson, and Robinson [2001].

statehist: Measure of the antiquity of a state (1 to $1950 \mathrm{CE}$ ) regarding the existence of native foreign government and the extent of the territory ruled by this government. The measure used corresponds to statehist5 of the database in Bockstette, Chanda, and Putterman [2002].

avgexpect: Average life expectancy at birth for the years 19601990, Children Data Bank for International.

socap: Measure of social capability derived by Adelman and Morris [1967] using assessment of each country's development as of 1957-1962 in a variety of respects such as extent of urbanization, extent of dualism, extent of social mobility, extent of literacy, crude fertility rate, degree of modernization of outlook, character of basic social organization, extent of mass communication, size of traditional agricultural sector and importance of indigenous middle class, Temple and Johnson [1998].

infra: Measure of social infrastructure (1986-1995) computed as the average of the GADP and an openness measures. GADP is an index of government antidiversion policies including law and order, bureaucratic quality, corruption, risk of expropriation, and government repudiation of contracts, Hall and Jones [1999].

avgmort: Average under-5 mortality rate for the years 1970 1990, Children Data Bank for International.

pop100cr: Percentage of population within $100 \mathrm{~km}$ of icefree coast, CID at Harvard University. General Measures of Geography.

tropop: Percentage of population in geographical tropics, CID at Harvard University. General Measures of Geography.

kkz: Composite index of six dimensions of governance: voice and accountability, political stability and absence of violence, government effectiveness, regulatory quality, rule of law, control of corruption, Kaufmann, Kraay, and Zoido-Lobatón [1999a, 1999b]. 
me: Malaria Ecology. An ecologically based variable that is predictive of the extent of malaria transmission [Kiszewski et al. 2004]. Malaria is intrinsically a disease of warm environments because a key part of the life-cycle of the parasite (sporogony) depends on a high ambient temperature. Malaria also depends on adequate conditions of mosquito breeding, mainly pools of clean water, usually due to rainfall ending up in puddles, cisterns, discarded tires, and the like. Additionally, the intensity of malaria transmission depends on the specific mosquito species that are present. The basic formula for Malaria Ecology combines temperature, mosquito abundance, and mosquito vector type. The underlying index is measured on a highly disaggregated subnational level, and then averaged for the entire country and weighted by population, The Earth Institute at Columbia University.

bureau: An index of the efficiency of the bureaucracy, ranging from 1 (least efficient) to 6 (most efficient). The data are averaged over the period 1992-1997. International Country Risk Guide (ICRG) at http://www.countrydata/datasets/.

exprisk: Expropriation risk. Assessment of risk of "outright confiscation" or "forced nationalization." It ranges from 0 to 10 , with lower scores indicating a higher risk. The data are averaged over the period 1992-1997. ICRG.

lat_abst: Distance from the equator scaled between 0 and $1, \mathrm{La}$ Porta, Lopez-de-Silanes, Shleifer, and Vishny [1998] — henceforth LLSV.

pr. rights: Property rights. Rating of property rights on a scale from 0 to 5 . The more protection private property receives, the higher the score, LLSV.

soe: Index of state-owned enterprises (SOE). Measures the role of SOEs in the economy, ranging from 0 to 10 . Higher scores denote countries with fewer government-owned enterprises, which are estimated to produce less of the country's output, LLSV.

corruption: Measure of corruption, with the scale ranging from 1 (high level of corruption) to 6 (low level). The data are averaged over the period 1992-1997. ICRG.

assass: Number of assassinations per 1000 inhabitants, averaged over 1960-1990, Banks [1994].

revc: Revolutions and coups. A revolution is defined as any illegal or forced change in the top of the governmental elite, any attempt at such a change, or any successful or unsuccessful armed rebellion whose aim is independence from central government. Coup 
d'Etat is defined as an extraconstitutional or forced change in the top of the governmental elite or its effective control of the nation's power structure in a given year or both. Unsuccessful coups are not counted. Data are averaged over 1960-1990, Banks [1994]. avelf: Ethnic fractionalization. Average value of five indices of ethnolinguistic fractionalization, with values ranging from 0 to 1 , where higher values denote higher levels of fractionalization, Easterly and Levine [1998].

rulelaw: Measure of the law and order tradition in a country. It ranges from 10, strong law and order tradition, to 1 , weak law and order tradition. The data are averaged over the period 19921997. ICRG.

bus. reg: Business regulation. Rating of regulation policies related to opening and keeping open a business. The scale is from 0 to 5 , with higher scores meaning that regulations are straightforward and applied uniformly to all businesses and that regulations are less of a burden to business, LLSV.

civil: Index of civil liberties, Freedom House 1994.

legal origins: Dummy variables for British (Eng), French (Fre), German (Ger) and Scandinavian legal origins, LLSV.

private credit: $\left\{(0.5)^{*}[F(t) / P e(t)+F(t-1) / P e(t-1)]\right\} /$ $[G D P(t) / P a(t)]$, where $F$ is credit by deposit money bank and other financial institutions to the private sectors (lines $22 \mathrm{~d}+$ $42 \mathrm{~d}$ ), GDP is line 99b, $P e$ is end- of period CPI (line 64) and $P a$ is the average CPI for the year, IFS.

bank assets: $\{(0.5) *[F(t) / P e(t)+F(t-1) / P e(t-1)]\} /[G D P(t) /$ $P a(t)$ ], where $F$ is domestic assets of deposit money banks (lines $22 \mathrm{a}-\mathrm{d}$ ), GDP is line 99b, $P e$ is end-of-period CPI (line 64), and $P a$ is the average CPI for the year, IFS.

liquid liabilities: $\{(0.5) *[F(t) / P e(t)+F(t-1) / P e(t-1)]\} /$ [GDP $(t) / P a(t)]$, where $F$ is liquid liabilities (line 55), GDP is line 99b, Pe is end-of-period CPI (line 64), and $P a$ is the average CPI for the year, IFS.

commercial-central bank: $D B A(t) /(D B A(t)+C B A(t))$, where $D B A$ is assets of deposit money banks (lines $22 \mathrm{a}-\mathrm{d}$ ) and $C B A$ is central bank assets (lines 12a-d), IFS.

bmp: Black market premium: Ratio of black market exchange rate and official exchange rate minus one, Picks' Currency Yearbook through 1989 and the World Currency Yearbook.

sec: Average years of secondary schooling in the population over fifteen from 1960-1995, Barro and Lee [1996]. 
school: Average years of schooling in the population over 25 in 1960, Barro and Lee [1996].

pi: Inflation rate. Log difference of consumer price index average from 1960-1995, IFS (line 64).

trade: Openness to trade. Sum of real exports and imports as a share of real GDP, average 1960-1995, Levine, Loayza, and Beck [2000], henceforth LLB.

gov: Government expenditure as a share of GDP, average 19601995, LLB.

africa: Dummy for countries in the African continent.

$\mathbf{y}-\mathbf{y}_{\mathbf{1}}$ : Difference between log per-capita real GDP 1960 in each country and the United States, LLB.

gschool: Average annual growth rate of schooling from 1960 to 1995, LLB.

hy: 1985 human-capital to output ratio, Klenow and RodríguezClare [1997].

ghy: 1960-1985 annual growth rate of human capital to output ratio, Klenow and Rodríguez-Clare [1997].

$\operatorname{lna}-\ln a_{1}$ : The log of productivity in 1960 relative to the United States, Benhabib and Spiegel [2005].

HARVARD UNIVERSITY

BROWN UNIVERSITY

Centro de Investigación y Docencia Económicas, MÉxico

\section{REFERENCES}

Acemoglu, Daron, Philippe Aghion, and Fabrizio Zilibotti, "Distance to Frontier, Selection and Economic Growth," National Bureau of Economic Research Working Paper No. 9066, July 2002.

Acemoglu, Daron, and Simon Johnson, "Unbundling Institutions," mimeograph, Massachusetts Institute of Technology, June 2003.

Acemoglu, Daron, Simon Johnson, and James A. Robinson, "The Colonial Origins of Comparative Development: An Empirical Investigation," American Economic Review, XCI (2001), 1369-1401.

Acemoglu, Daron, and Fabrizio Zilibotti, "Productivity Differences," Quarterly Journal of Economics, CXVI (2001), 563-606.

Adelman, Irma, and Cynthia Taft Morris, Society, Politics and Economic Development: A Quantitative Approach (Baltimore, MD: The Johns Hopkins University Press, 1967).

Aghion, Philippe, Abhijit V. Banerjee, and Thomas Piketty, "Dualism and Macroeconomic Volatility," Quarterly Journal of Economics, CXIV (1999), 1359-1397.

Aghion, Philippe, and Patrick Bolton, "A Model of Trickle-Down Growth and Development," Review of Economic Studies, LXIV (1997), 151-172.

Aghion, Philippe, and Peter Howitt, Endogenous Growth Theory (Cambridge, MA: MIT Press, 1998).

Aghion, Philippe, Peter Howitt, and David Mayer-Foulkes, "The Effect of Financial Development on Convergence: Theory and Evidence," National Bureau of Economic Research Working Paper No. 10358, March 2004. 
Alfaro, Laura, Areendam Chanda, Sebnem Kalemli-Ozcan, and Selin Sayek, "FDI and Economic Growth: The Role of Local Financial Markets," mimeograph, University of Houston, 2003.

Arrow, Kenneth J., "Classificatory Notes on the Production and Transmission of Technological Knowledge," American Economic Review, LIX (1969), 29-35.

Baily, Martin Neil, and Robert M. Solow, "International Productivity Comparisons Built from the Firm Level," Journal of Economic Perspectives, XV (2001), 151-172.

Banerjee, Abhijit, "Contracting Constraints, Credit Markets and Economic Development," in Matthias Dewatripont, Lars-Peter Hansen, and Stephen J. Turnovsky, eds., Advances in Economics and Econometrics (New York, NY: Cambridge University Press, 2003).

Banerjee, Abhijit, and Andrew Newman, "Occupational Choice and the Process of Development," Journal of Political Economy, CI (1993), 274-298.

Banks, Arthur S., "Cross-National Time Series Data Archive," Center for Social Analysis, University of New York at Binghampton, 1994.

Barro, Robert J., and Jong-Wha Lee, "International Measures of Schooling Years and Schooling Quality," American Economic Review, LXXXVI (1996), $218-224$.

Barro, Robert J., and Xavier Sala-i-Martin, "Convergence," Journal of Political Economy, C (1992), 223-251.

Barro, Robert J., and Xavier Sala-i-Martin, "Technological Diffusion, Convergence, and Growth," Journal of Economic Growth, II (1997), 1-26.

Basu, Susanto, and David N. Weil, "Appropriate Technology and Growth," Quarterly Journal of Economics, CXIII (1998), 1025-1054.

Beck, Thorsten, Asli Demirgüç-Kunt, and Ross Levine, "Law, Endowments, and Finance," Journal of Financial Economics, LXX (2003), 137-181.

Beck, Thorsten, Ross Levine, and Norman Loayza, "Finance and the Sources of Growth," Journal of Financial Economics, LVIII (2000), 261-300.

Bencivenga, Valerie R., and Bruce D. Smith, "Financial Intermediation and Endogenous Growth," Review of Economic Studies, LVIII (1991), 195-210.

Bencivenga, Valerie R., and Bruce D. Smith, "Some Consequences of Credit Rationing in an Endogenous Growth Model," Journal of Economic Dynamics and Control, XVII (1993), 97-122.

Benhabib, Jess, and Mark M. Spiegel, "Cross-Country Growth Regressions," New York University Working Paper, 1997.

Benhabib, Jess, and Mark M. Spiegel, "The Role of Financial Development in Growth and Investment," Journal of Economic Growth, V (2000), 341-360.

Benhabib, Jess, and Mark M. Spiegel, "Human Capital and Technology Diffusion," in Philippe Aghion and Steven N. Durlauf, eds., Handbook of Economic Growth (Amsterdam: Elsevier, 2005), forthcoming.

Bernanke, Ben, and Mark Gertler, "Agency Costs, Net Worth, and Business Fluctuations," American Economic Review, LXXIX (1989), 14-31.

Blackburn, Keith, and Victor T. Y. Hung, "A Theory of Growth, Financial Development and Trade," Economica, LXV (1998), 107-124.

Bockstette, Valerie, Areendam Chanda, and Louis Putterman, "States and Markets: The Advantage of an Early Start," Journal of Economic Growth, VII (2002), 347-369.

Cohen, Wesley M., and Daniel A. Levinthal, "Innovation and Learning: The Two Faces of R\&D," Economic Journal, XCIX (1989), 569-596.

Davidson, Russell, and James G. MacKinnon, Econometric Theory and Methods (New York, NY: Oxford University Press, 2004).

De Gregorio, José, "Borrowing Constraints, Human Capital Accumulation, and Growth," Journal of Monetary Economics, XXXVII (1996), 49-71.

Demirgüç-Kunt, Asli, and Ross Levine, Financial Structure and Economic Growth: A Cross-Country Comparison of Banks, Markets, and Development (Cambridge, MA: MIT Press, 2001).

Djankov, Simeon, Rafael La Porta, Florencio Lopez-de-Silanes, and Andrei Shleifer, "The Regulation of Entry," National Bureau of Economic Research Working Paper No. 7892, September 2000.

Easterly, William, and Ross Levine, "Troubles with the Neighbours: Africa's 
Problems and Africa's Opportunities," Journal of African Economics, VII (1998), 120-142.

Easterly, William, and Ross Levine, "It's Not Factor Accumulation: Stylized Facts and Growth Models," World Bank Economic Review, XV (2001), 177-219.

Evans, Paul, "Using Cross-Country Variances to Evaluate Growth Theories," Journal of Economic Dynamics and Control, XX (1996), 1027-1049.

Evenson, Robert E., and Larry E. Westphal, "Technological Change and Technology Strategy," in T. N. Srinivasan and Jere Behrman, eds., Handbook of Development Economics, Vol. 3A (Amsterdam: Elsevier, 1995).

de la Fuente, Angel, and José Maria Marin, "Innovation, Bank Monitoring, and Endogenous Financial Development," Journal of Monetary Economics, XXVIII (1996), 269-301.

Galetovic, Alexander, "Specialization, Intermediation, and Growth," Journal of Monetary Economics, XXVIII (1996), 549-559.

Galor, Oded, and David Weil, "Population, Technology, and Growth: From Malthusian Stagnation to the Demographic Transition and Beyond," American Economic Review, XC (2000), 806-828.

Galor, Oded, and Joseph Zeira, "Income Distribution and Macroeconomics," Review of Economic Studies, LX (1993), 35-52.

Gerschenkron, Alexander, "Economic Backwardness in Historical Perspective," in Bert F. Hoselitz, ed., The Progress of Underdeveloped Areas (Chicago, IL: University of Chicago Press, 1952).

Gollin, Douglas, Stephen Parente, and Richard Rogerson, "The Role of Agriculture in Development," American Economic Review Papers and Proceedings, XCII (2002), 160-164.

Greenwood, Jeremy, and Boyan Jovanovic, "Financial Development, Growth, and the Distribution of Income," Journal of Political Economy, XCVIII (1990), $1076-1107$.

Griffith, Rachel, Stephen Redding, and John Van Reenen, "Mapping the Two Faces of R\&D: Productivity Growth in a Panel of OECD Industries," mimeograph, University College London, August 2001.

Grossman, Gene M., and Elhanan Helpman, Innovation and Growth in the Global Economy (Cambridge, MA: MIT Press, 1991).

Hall, Robert E., and Charles I. Jones, "Why Do Some Countries Produce so Much More Output per Worker than Others?" Quarterly Journal of Economics, CXIV (1999), 83-116.

Hansen, Gary D., and Edward C. Prescott, "Malthus to Solow," American Economic Review, CXII (2002), 1205-1217.

Harrison, Paul, Oren Sussman, and Joseph Zeira, "Finance and Growth: Theory and New Evidence," Board of Governors of the Federal Reserve System, Finance and Economics Discussion Series 99/35, July 1999.

Hauk, William R., Jr., and Romain Wacziarg, "A Monte Carlo Study of Growth Regressions," National Bureau of Economic Research Technical Working Paper No. 296, January 2004.

Howitt, Peter, "Steady Endogenous Growth with Population and R\&D Inputs Growing," Journal of Political Economy, CVII (1999), 715-730.

—_ "Endogenous Growth and Cross-Country Income Differences," American Economic Review, XC (2000), 829-846.

Howitt, Peter, and David Mayer-Foulkes, "R\&D, Implementation and Stagnation: A Schumpeterian Theory of Convergence Clubs," National Bureau of Economic Research Working Paper No. 9104, August 2002.

Jones, Charles I., "R\&D-Based Models of Economic Growth," Journal of Political Economy, CIII (1995), 759-784.

Kahn, Aubhik, "Financial Development and Economic Growth," Macroeconomic Dynamics, V (2001), 413-433.

Kaufmann, D., A. Kraay, and P. Zoido-Lobatón, "Aggregating Governance Indicators," World Bank Research Working Paper No. 2195, 1999a.

Kaufmann, D., A. Kraay, and P. Zoido-Lobatón, "Governance Matters," World Bank Research Working Paper No. 2196, 1999b.

Keller, Wolfgang, "Technology Diffusion and the World Distribution of Income: The Role of Geography, Language, and Trade," mimeograph, University of Texas, June 2002. 
King, Robert G., and Ross Levine, "Finance and Growth: Schumpeter Might Be Right," Quarterly Journal of Economics, CVIII (1993a), 717-737.

King, Robert G., and Ross Levine, "Finance, Entrepreneurship, and Growth," Journal of Monetary Economics, XXXII (1993b), 513-542.

Kiszewski, Anthony, Andrew Mellinger, Andrew Spielman, Pia Malaney, Sonia Ehrlich Sachs, and Jeffrey Sachs, "A Global Index Representing the Stability of Malaria Transmission," American Journal of Tropical Medicine and Hygiene, LXX (2004), 486-498.

Klenow, Peter J., and Andrés Rodríguez-Clare, "The Neoclassical Revival in Growth Economics: Has it Gone too Far?" in Ben Bernanke and Julio Rotemberg, eds., NBER Macroeconomics Annual 1997 (Cambridge, MA: MIT Press, 1997).

Krebs, Tom, "Human Capital Risk and Economic Growth," Quarterly Journal of Economics, CXVIII (2003), 709-744.

La Porta, Rafael, Florencio Lopez-de-Silanes, Andrei Shleifer, and Robert W. Vishny, "Legal Determinants of External Finance," Journal of Finance, LII (1997), 1131-1150.

La Porta, Rafael, Florencio Lopez-de-Silanes, Andrei Shleifer, and Robert W. Vishny, "Law and Finance," Journal of Political Economy, CVI (1998), 1113-1155.

Levine, Ross, "Stock Markets, Growth, and Tax Policy," Journal of Finance, XLVI (1991), 1445-1465.

_- "Financial Development and Economic Growth: Views and Agenda," Journal of Economic Literature, XXXV (1997), 688-726.

- "Finance and Growth: Theory, Evidence, and Mechanisms," in Philippe Aghion and Steven N. Durlauf, eds., Handbook of Economic Growth (Amsterdam: Elsevier, 2005), forthcoming.

Levine, Ross, Norman Loayza, and Thorsten Beck, "Financial Intermediation and Growth: Causality and Causes," Journal of Monetary Economics, LXVI (2000), 31-77.

Lucas, Robert E., Jr., "Why Doesn't Capital Flow from Rich to Poor Countries?" American Economic Review Papers and Proceedings, LXXX (1990), 92-96.

Maddison, Angus, The World Economy: A Millennial Perspective (Paris, France: OECD, 2001).

Mankiw, N. Gregory, David Romer, and David N. Weil, "A Contribution to the Empirics of Economic Growth," Quarterly Journal of Economics, CVII (1992), 407-437.

Mayer-Foulkes, David, "Global Divergence," Documento de Trabajo del CIDE, SDTE 250, División de Economía, 2002.

Morales, María F., "Financial Intermediation in a Model of Growth through Creative Destruction," Macroeconomic Dynamics, VII (2003), 363-393.

Nelson, Richard, and Edmund S. Phelps, "Investment in Humans, Technological Diffusion, and Economic Growth," American Economic Review, LVI (1966), 69-75.

Parente, Stephen L., and Edward C. Prescott, "Technology Adoption and Growth," Journal of Political Economy, CII (1994), 298-321.

Parente, Stephen L., and Edward C. Prescott, "Monopoly Rights: A Barrier to Riches," American Economic Review, LXXXIX (1999), 1216-1233.

Piketty, Thomas, "The Dynamics of the Wealth Distribution and the Interest Rate with Credit Rationing," Review of Economic Studies, LXIV (1997), 173-189.

Pritchett, Lant, "Divergence, Big-Time," Journal of Economic Perspectives, XI (1997), 3-17.

Saint-Paul, Gilles, "Technology Choice, Financial Markets and Economic Development," European Economic Review, XXXVI (1992), 763-781.

Sussman, Oren, "A Theory of Financial Development," in A. Giovannini, ed., Finance and Development: Issues and Experience (New York, NY: Cambridge University Press, 1993).

Temple, Jonathan, and Paul A. Johnson, "Social Capability and Economic Growth," Quarterly Journal of Economics, CXIII (1998), 965-990. 